\title{
Typhoon Simulation incorporating Effects of Sea-Surface Temperature
}

\author{
勝地 $弓^{* 1}$,山田 均 ${ }^{* 2}$, 宮田利雄 ${ }^{*} 3$, 斎藤智久 ${ }^{* 4}$ \\ Hiroshi KATSUCHI, Hitoshi YAMADA, Toshio MIYATA and Tomohisa SAITO
}

\section{SUMMARY}

Large-scale and/or long-span structures, which must be sustained for long service life, are susceptible to strong winds. Their design wind speeds are mostly decided by typhoons in Japan. Global warming typically causing the increase of the sea-surface temperature would affect, probably intensify typhoons approaching Japan. In order to investigate the effects of the increase of the sea-surface temperature on typhoon frequency and intensity, a new typhoon simulation technique was developed incorporating the sea-surface temperature. The new simulation technique predicted future trends due to the increase of the sea-surface temperature that the number of typhoon approaching Japan increased and depression of the central pressure increased. It was also shown that 100-year recurrence wind speeds in 24 regions in Japan increased by 10 $-15 \%$ on the average due to future increase of the sea-surface temperature.

Key words: Typhoon simulation, Global warming, Sea-surface temperature, Recurrence wind speed

\section{1.まえがき}

日本においては多くの地域で年最大風速が台風によ って決定される。乥れゆえ,構造物の設計風速を論じる 際には,台風頻度, 強度が重要な要因となる.台風は熱 帯収束帯て発生し,中でも北緯 $10^{\circ} \sim 20^{\circ}$ 程度の海域 で最も発生頻度が高〈なる.過去の統計データによると， 台風の発生は海面水温が $27^{\circ} \mathrm{C}$ 程度以上で活発となるこ とが示されており1)，高い海面水温がより多〈の水蒸気を 台風に供給し,発達を促進する.このことから, 海面水温 は台風の発生,盛衰に大きな影響を与えることになる． 昨今, 地球温暖化か叫ばれており,光の影響の1つに海 面水温の上昇がある.気象庁による地球温暖化予測情 報 ${ }^{2}$ によると，温暖化のシナリオにも依存するが，日本の 南海では今後 100 年間に最大で $3 \sim 4^{\circ} \mathrm{C}$ の海面水温の 上昇が見込まれている.地球温暖化が進むことで台風
への水蒸気供給も一層活発になり,日本に来襲する台 風の頻度，強度も相当の影響を受けることが予想される。 その結果,数十年あるいは光れ以上の期間で見た場合， 構造物を取り巻〈強風環境は大き変化することになり， 地球温暖化による海面水温の変化と台風頻度, 強度と の定量的な関係を明らかにすることか求められる.

再現期待風速を求める手法としては,過去の年最大 風速記録による極值統計解析が用いられることが多いが， この手法では 30〜 50 年程度の記録から 100 年 , 150 年 の再現期待値を外挿することとなる.一方,台風の統計 データから発生頻度, 強度, 移動速度, 移動方向などの 確率モデルを作成し,確率的にシミュレートする,いわゆ る台風シミュレーシシン手法が考案され，一部で害用化さ れている.この手法によれば ,十分に長い期間でのシミ ユレーシシをを実施することで,確率的に安定した推定結

\section{* 1 横浜国立大学大学院工学研究院 助教授}

Associate Professor, Department of Civil Engineering, Yokohama National University

* 2 横浜国立大学大学院環境情報研究院 教授

Professor, Department of Civil Engineering, Yokohama National University

* 3 横浜国立大学 名誉教授

Professor Emeritus, Yokohama National University

* $4 \mathrm{JFE}$ エンジニアリクグ 株) シビルエンジニアリノク部 研究当時 横浜国立大学大学院) Engineer, JFE Engineering Co. (Former Graduate Student of Yokohama National University) 
果を得ることが出来るが,一方で確率モデルの精度と地 上風への変換とい㗴題も含んでいる.

以上の議論を踏まえ，筆者らは既往の台風シミュレー ション手法を発展させ,海面水温パラメターを新たに導 入することを試みてきた ${ }^{3)}$.文献 3 では，過去 50 年間に 発生した全ての台風統計データ 発生位置, 発生時強 度, 移動時のベクトル速度) と海面水温を分析し,台風の 発生位置, 発生時強度を含む台風の確率モデルを構筑 し,海面水温の影響を取り込んだ確率的なシミュレーショ ンによって日本に来襲する台風強度特性を解析した。㫕 こでは,台風の強度特性を定量的に議論するまでには 至らなかったが,海面水温を台風シミュレーシシンに有効 に取り込み得ることを示した。

乥こで本研究では,まず台風の定義域を実質的に包 含出来るまでに解析領域を拡げ，台風の確率モデルの 再構築を行った.このモデルを使用すれば,台風発生 時から消滅時までを完全にシミュレートすることができ， 谷の盛衰過程に密接に関係を持つ海面水温の影響を 合理的かつ効果的に考慮できることになる.次に，海面 水温の影響を考慮した台風シミュレーシシンを実施し，日 本各地での台風頻度, 強度および再現期待風速を求め た.さらに海面水温や关の変化が台風強度特性に及ぼ す影響について定量的な分析を行った.なお，東北地 方や北海道では一般に台風以外の強風が年最大風速 となることが多いが,本研究では海面水温の変化が台風 強度特性に与える影響を検討することを目的としたため， 日本全域を検討の対象とした .

2 .台風強度特性のシミュレーションと海面水温

2.1 既往の台風シミュレーション

再現期待風速を過去の年最大風速統計によらず,確 率モデルを使ったシミュレーシジによって求めようとする 試みが，日本ではまず高橋によって提案されている4). 高橋は西日本を対象に,台風中心気圧と中心までの距 離を乱数で確率的にシミュレール,対象地点の年最大 風速を求めた.乥して, 台風の年発生数を平均 3.5 のポ アソン分布と仮定し,シミュレーシシンを繰り返すことで再 現期待風速力確率的に求められるとした .また, 海外で は, Russel ${ }^{5}$ が台風の発生頻度, 海岸線を横切る位置, 移動速度, 移動方向を確率的にシミュレート,台風の 風速場モデルから風速を算出して再現期待風速を求め ている.光の後, Tryggvason ら ${ }^{6} や$ Georgiou ら $ら^{7}$ Russel の手法にならって台風シミュレーションを行っているが， いずれも台風の移動コースを直線としたり，比較的狭い 範囲でのシミュレーシシンであり,初期段階のものと位置 づけられる.

一方,日本においては,藤井,光田が,1951 年から 1984 年までの 49 個の顕著台風 止陸時の中心気圧が 980hPa 以下) をもとに, 中心気圧低下量, 最大旋衡風速 半径, 移動速度, 移動方向の確率モデルを 3 分割した 関東以西の海岸線毎に作成し，光れをもとにシミュレー ションを行って, 台風コ一スや明石海峡での年最大風速 を再現した ${ }^{8)}$.この手法では, 海岸線および光の延長線 上から台風シミュレーションを開始しており,上陸後の中 心気圧低下量は経過時間とともに指数的に減衰するとし
ているものの,移動方向は不変としている.

さらに,光田,藤井は,北緯 $23^{\circ}$ から $39^{\circ}$,東経 $123^{\circ}$ から $147^{\circ}$ の地域を考え，この領域でのシミュレー ションを検討した ${ }^{9)}$.具体的には ,1951 年から 1994 年ま でに対象地域に進入もしくは，乥こで発生した 578 個の 台風特性を分析し,領域内の緯度方向 $2^{\circ}$, 経度方向 $4^{\circ}$ の小領域毎に 6 時間後の南北, 東西移動速度を予 測する線形回帰式を構築した .乥して ,6 時間毎の值を 次々と確率的にシミュレー忖ることで台風の進路を再現 することを試みた。しかしながら,台風の発生, 盛衰, 進 路を全ての台風について,長期期間にわたつてシミュレ 一忖ることは将来の課題としている.

ところで,台風シミュレーシジにおける課題の1つに地 上風速の推定があるが,松井らは大気境界層の物理的 考察から導かれた台風気圧場と相当粗度長を用いて地 上風速を求める式を藤井 光田の方法に取り込み，千葉 気象台での実測値とよ対応することを示した ${ }^{10)}$.

さらに,安井ら ${ }^{11}$ は,対象領域を北緯 $24^{\circ}$ から $50^{\circ}$ ， 東経 $113^{\circ}$ から $152^{\circ}$ に拡大し, 格子分割も緯度方向 $2^{\circ}$,経度方向 $3^{\circ}$ と経度方向について細分化を行った。 1951 年から1995 年までの中心気圧が $980 \mathrm{hPa}$ 以下に低 下した台風を対象に統計的特性を調査し,台風発生域 を北緯 $24^{\circ}$ から $26^{\circ}$ に限定して, 台風発生時の中心気 圧低下量, 東西, 南北移動速度を正規分布でモデル化 した.弚して,6 時間後の中心気圧低下量, 東西, 南北 移動速度を予測する線形回帰式を各格子毎に定義し， シミユレーションを実施した .また,シミュレートた台風 の中心位置, 中心気圧低下量, 移動速度, 最大旋衡風 速半径から傾度風速を求め,換算した海上風速と観測 值を比較するとともに,台風モデルの平均化時間, 移動 平均值周りの 10 分間平均風速の確率分布について検 討を行った。

以上のように,台風統計に基づ〈台風シミュレーション 手法はかなりの改良がなされてきており,実際，実務設 計の場でも用いられ始めている.ただ ,关の精度か確率 モデルの精度に依存していること,推定される上空風速 傾度風速）と地上風速との関係が明確でないことが今 後の検討課題となっている.また，過去の統計が将来に わたって適用し得るといj前提に立っている点も注意が 必要である.本研究では, 以上述べた既往の手法をさら に発展させる形で每面水温という゚ラメターを新たに取り 込み, 乥れか将来の台風強度特性に与える影響をシミュ レーショによって検討することを新たな取り組みとした .

一方,過去の統計によらずに地球上の境界層を 3 次 元的に格子分割し,差分法などによる数值解析よって， 大気運動を直接シミュレートすることが行われており,天 気予報に使われている.ただ，現段階では台風規模の 擾乱を精度よくシミュレートできるほどの格子分割には至 っておらず，また長い将来に渡ってのシミュレーションも 不可能であることから,この点においても統計データに 基づ〈台風シミュレーシジ手法はいまだ有効な゙ソールと 言える。

\section{2 海面水温と台風強度の関係}

地球温暖化に伴海面水温の上昇と台風強度の関係 
については これまでにいくつかの研究結果が得られて いる ${ }^{12)}$.以下に主なものを概観する。

Ryan らは, Gray ${ }^{13)}$ か提案した 6 つの因子から熱帯低 気压の発生数を推定する式を用いて, 地球温暖化に伴 海面水温の上昇によって熱帯低気圧の発生数力増加

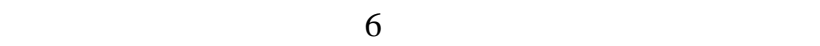
水温が $26^{\circ}$ よ何度高いかとい洇子によって，この計 算結果がもたらされるが, この予測結果は現在の気候条 件での海面水温と熱帯低気圧の発生数との統計的関係 か地球温暖化時にも炎のまま適用できるという前提があ ることに注意しなければならない .

Emanuel は,熱帯低気圧をカルノーサイクルとい爇 機関の一種の理論モデルと見なして, 海面水温と台風 の強さの関係を計算した .乥して, 海面水温が $3^{\circ}$ 高〈な ると, 熱帯低気圧が取り得る最大の中心気圧低下量が 30〜 $40 \%$ 大き〈なり, 最大風速は 15〜20\%増大するとい 結果を得ている ${ }^{15)}$.ただ ,ここでの計算は単純化された モデルによるものであり,弚の結果は上限値を示すもの であって平均的な值を議論しているものではないことに 注意が必要である。

一方，日本においても同樣の研究がなされている.筒 井,平口は,台風の発生数との統計的な関係を調へ，比 較的弱い台風は海面水温との相関が高いが,強い台風 の数は相関が低いとい結果を得ている ${ }^{16)}$ 。また ,山 田 ${ }^{17)}$ おび DeMaria and Kaplan ${ }^{18)}$ は,ハリケーンと台風 について,平均的な強さと海面水温との間には有為な関 係は見つからなかつたが,強さの 95 パーセンタイル值な どの上限值は海面水温とともに増加してい〈傾向にあつ たとしている.一方, 丸山らが過去 43 年間の統計データ を解析した結果, 台風の発生域の海面水温と台風の強 さの間にはほとんと関係がないとい結果を得ている ${ }^{19)}$.

さらに,Sugi, et al ${ }^{20}{ }^{20}$ は,大気境界層の物理モデルを 用いた数值シミュレーションによって地球温暖化が台風 強度に与える影響を検討している.これは，気象庁の大 気循環モデル IMA-GSM8911, 格子解像度 $1.1^{\circ} \times$ $\left.1.1^{\circ}\right)$ を用いて 10 年間のシミュレーションを実施し,海 面水温上昇の台風への影響を検討したものである.弚の 結果, 海面水温の上昇 女気中の二酸化炭素濃度が 2 倍になった場合)は, 北太平洋地域での著しい台風個数 の減少をもたらす結果となった .ただし，比較実験として 実施した現状でのシミュレーシジにおいても，観測值よ りも少ない台風個数と小さい台風強度を示しており,解 析精度 特に, 格子解像度)の改良が必要であるとして いる.

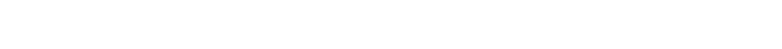
見られるが,海面水温の上昇によって台風発生数や台 風強度に少なくとも正の影響をもたらすことは言えそうで ある。

3 .海面水温を考慮した台風シミュレーション手法の構 築

\section{1 シミュレーション手法の概要}

本研究でのシミュレーション手法の基本的枠組みは， 光田,藤井の提案したもの ${ }^{9}$ をベースにしている.ただし， 本研究では台風発生地点のシミュレーシジから始まり,
兰の後の台風の移動および盛衰という台風の一生涯を 逐一シミュレートする手法を用いた .具体的には,図ー1 に示すよう過去の台風統計データから台風発生数， 発生位置を確率的にシミュレート，同時に発生時の中 心気圧低下量, 東西および南北移動速度の 3 つのパラ メターを確率的にシミュレートた，次に，台風中心位置 が存在する解析格子に依存する先の 3 つのパラメ久ーを 6 時間毎に次々に確率的に更新していく手順を取った . この手順により,台風発生時から移動, 消滅までの台風 軌跡と炎の盛衰を確率的にシミュレー㤕来ることにな る。

特に本研究では, 海面水温が台風の強度, すなわち 盛衰に与える影響をシミュレートすることを目的としてい るため, 台風の発生時点から炎の強度, 移動特性をシミ ユレートする必要がある.このため,本研究では,6 時間 毎にパラメタ一值を更新する際に統計データを基に構筑 した海面水温の影響を考慮した回帰式を用いることで， 台風強度及び移動速度に与える海面水温の影響をシミ ユレートた。

気象庁の定義によると,台風はマレー半島から東経 $180^{\circ}$ の日付変更線までの北西太平洋上で発生する熱 帯低気圧のjち, 中心付近の最大風速が $17 \mathrm{~m} / \mathrm{s}$ 以上

1951 年からの定義)のものとされている.気象庁の 1951 年〜2000 年までの台風経路位置情報データによると， 台風の発生は図 - 2こ示すよう二北緯 $4 \circ$ 以北て顕著と なっている.本研究では,日本に来襲する台風を発生地

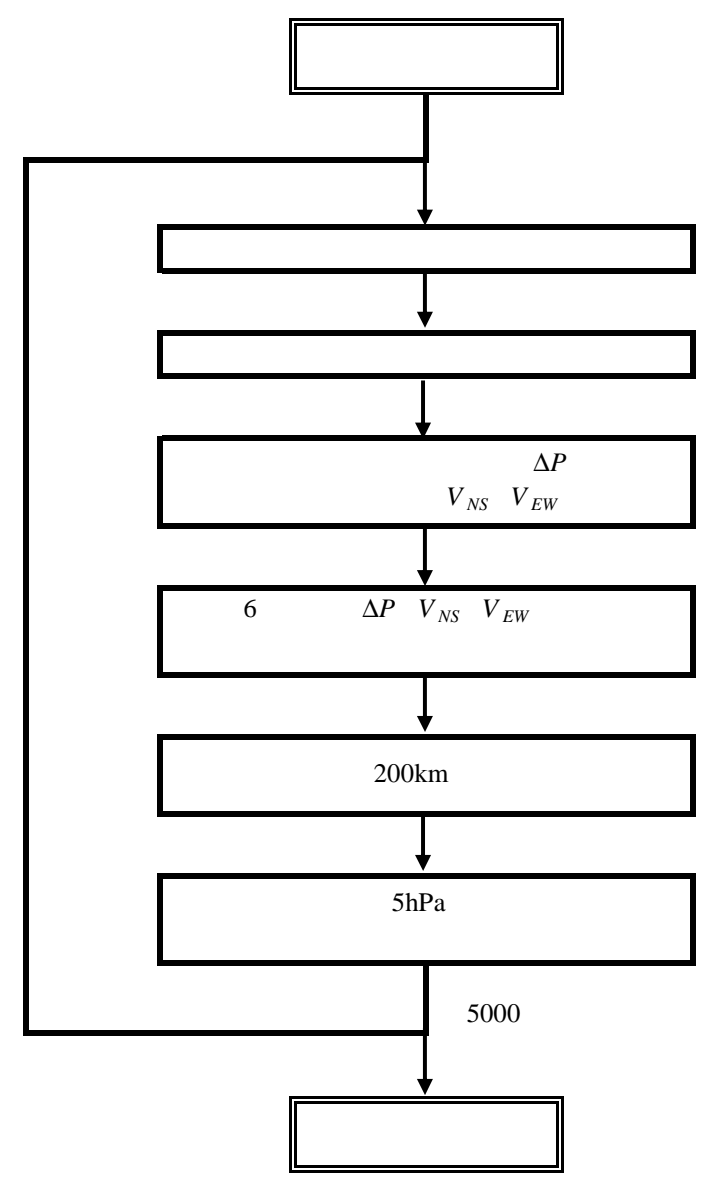

図 - 1 台風シミュレーシジフロー 


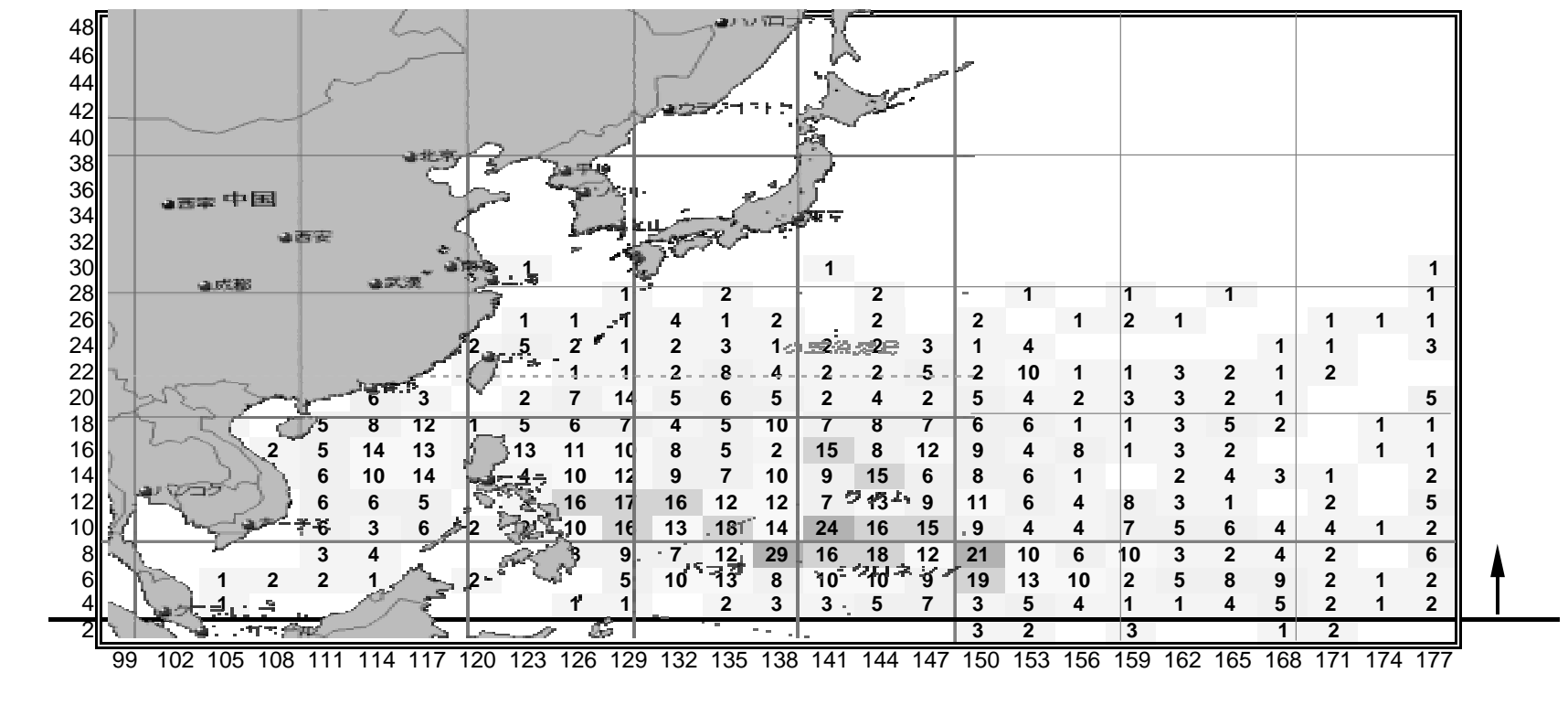

図 - 2 シミュレーシジ領域の台風発生数の統計 1951〜2000 年の累計)

点からシミュレートすることを目的としたため,シミュレー

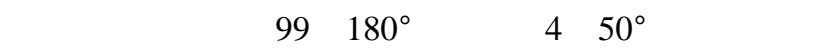
北緯 $2 \sim 4^{\circ}$ は発生数が少ないため除外した）.

また ,格子の分割については,シミュレーシシンステッ プの 6 時間での台風の移動距離を調べた結果, 東西 経度)方向には土 $3^{\circ}$,南北 緯度)方向には土 $2^{\circ}$ に ほぼ収まっていたことと,安井らの手法 ${ }^{11)}$ にならって, 東 西方向 $3^{\circ}$,南北方向 $2^{\circ}$ の分割とし,全体での格子数 を621 とした図－1参照).なお，シミユレーシシンにおけ る計算の便宜を考え,シミュレーション領域の南西端格

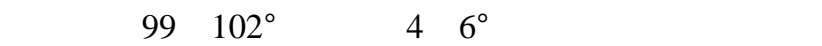
から同緯度で東へ進み,27 番目の最東端格子 東経 177〜 180 ) へ達したら1つ北北緯 6〜 $8^{\circ}$ )の最西端 東経 99〜 102 ${ }^{\circ}$ ) 格子へ戻って 28 番とし, 再度東へ進 む繰り返しによって,最終的に 621 番目の北東端格子

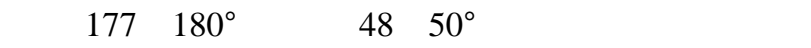
付けた。

\section{2 台風発生時の特性}

シミュレーショでの台風発生領域としては, 図 - んに 示す過去 1951〜2000 年)の台風発生領域を概ね包括 する北緯 $4^{\circ}$ から北緯 $32^{\circ}$ とした 北緯 2 4 $4^{\circ}$ は, 発生 数が少ないため除外した）.弚して，この台風発生数を基 に台風発生位置の確率分布モデルを作成した.すなわ ち,対象とした台風発生領域 北緯 4〜32 ${ }^{\circ}$,東経 99〜 $\left.180^{\circ}\right)$ )解析格子に若番側から確率密度 あるいは累 積確率)を与え,モンテカルロシミュレーションによ(発生 位置を決めた .また, 台風の年発生数は, 同じ統計デー 夕に基づくと, 図一 ろに示すよう平均 26.9 ,標準偏差 4.83 の正規分布で表現できる $\chi^{2}$ 検定で $5 \%$ 有意水準を 満たす)ことから,本研究における台風の年発生数は $N\left(26.9,4.83^{2}\right)$ の正規確率変数とした.具体的には, 最初 に正規乱数により台風の年発生数を決め四捨五入によ る整数止め), 次にモンテカルロシミュレーシシンにより午

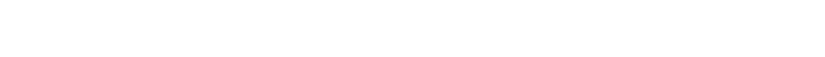
風発生数をポアソン分布でモデル化するのが一般的で あるが, 乥こでは限られた地域の台風通過個数や上陸 個数など,3〜 5 程度の平均値を持つ確率変数を考えて いる.本研究では, 地域を限定せず台風の年発生数 平 均 26.9 ,標準偏差 4.83$)$ を確率変数として扱っているが, この場合，正規分布とポアソン分布はほとんど同じ分布 を示すことから,本研究ではシミュレーションの便宜を考 えて,台風の年発生数は正規分布でモデル化した .

また, 本研究では海面水温が台風強度特性に与える 影響を検討することとしているが,過去の台風データを 分析した結果, 図一4に示すよう 50 年間で台風の平 均発生緯度 各年平均) 力約 $1.5^{\circ}$ 北上していること力判 った.したがって, 将来の予測海面水温を用いてシミュレ ーションを行暢合には, 図 - 2に示す台風発生位置の 確率分布を,乥の北上割合に従って北へシフトさせるこ とで, この効果を考慮することとした .台風の平均発生緯 度は,年変動はあるもののほぼ一定の北上割合を示して いるように見える.なお,台風発生個数は, 年による変動 はあるものの経年変化はほとんど見られないことから,本 研究では発生位置の経年変化のみを考慮することとし た。

気象庁の定義によると,台風の発生とはマレ一半島 以東, 東経 $180^{\circ}$ 以西の北太平洋上において熱帯低気 圧の中心付近最大風速が $17 \mathrm{~m} / \mathrm{s}$ 以上に達した時点の他 に,東経 $180^{\circ}$ 以東 西経域)から進入してきた台風に対 しても光の時点が発生時刻となる.したがって，発生時の 中心気圧低下量力純粋な発生時のものと異なり,特に東 端から領域に入る時には既に発達し大きな中心気圧低 下量を持ったものとなる.本研究では, 解析領域で台風 に発達したものだけを対象に確率モデルを構築すること とし,台風統計データと図 - 5に示す台風発生時の中心 気圧低下量の確率密度を勘案して, 発生時中心気圧低 下量が 30hPa 以下のものについて確率モデルを構築し 
た.なお,本研究での中心気圧低下量は,標準大気圧 1013hPa)と中心気圧との差とした .

兴の結果,台風発生時の中心気圧低下量は,図 -5 に示すよう平均 $8.54 \mathrm{hPa}$,標準偏差 $3.55 \mathrm{hPa}$ の正規分 布に従うことが判った $\chi^{2}$ 検定で $5 \%$ 有意水準を満たす). なお,シミュレーシジにおいては,年発生個数と発生位 置を決めた後, 正規乱数によって発生時中心気圧低下 量を決定した。

また, 発生時における南北, 東西方向の台風移動速 度伙れ艺れ北向き,東向きを正とする)は,過去の台風 発生時および移動時)デー多から各解析格子毎に構築 した台風移動速度の確率分布モデルを使って,モンテ カルロシミュレーションによって決定した .なお,本来は 発生時のみの移動速度統計から構築した確率分布モデ ルを用いるべきであるが,デー条数が少ないことと, 両者 に乥れほどの差異がなかったことから，発生時，移動時 を区別することなく各解析格子の移動速度特性として用 いることとした .図 - 6に各解析格子の確率分布モデル の平均値と標準偏差を示す.横軸は解析格子番号順の ため,同一緯度内での值の広がりはあるものの,台風の 移動速度に関しては，低緯度地域では西に進み,緯度 が高くなるにつれて次第に向きを東へ変えながら速度を
速めていることがよく判る.また, 南北方向に関しても, 低 緯度から高緯度になるにつれて速度が速まることか理解 される.

一方,中心気圧低下量については,緯度の北上に伴 い大きくなり,転向点付近で最大となった後, 減衰してい 〈台風の盛衰過程がよ〈理解される.なお，図－бて移動 速度に比べて,中心気圧低下量のばらつきが大きいの は,同じ解析格子データでも台風発生時と移動時のもの とが混在しているためである.したがって , 図 - 5に示す 台風発生時の中心気圧低下量は, 図 - 6の下限付近に 対応することとなる.

なお，中心気圧低下量，移動速度ともに，発生時は 乱数によっで決定し, 弚の後の移動においても次節て述 べるように 6 時間後の值を線形回帰式と乱数による誤差 を考慮して逐次更新していくため，場合によっては非現 実な值になることも予想される.既往の台風観測記録で は最低中心気圧 $870 \mathrm{hPa}$ であること,また移動速度は日 本の北東海上でも $100 \mathrm{~km} / \mathrm{h}$ 以下と考えられることから， 本研究では中心気圧低下量, 移動速度に关れ光れ $150 \mathrm{hPa}, 100 \mathrm{~km} / \mathrm{h}$ の上限値を設定して頭打ちとすること で,非現実な値の出現を避けることとした .

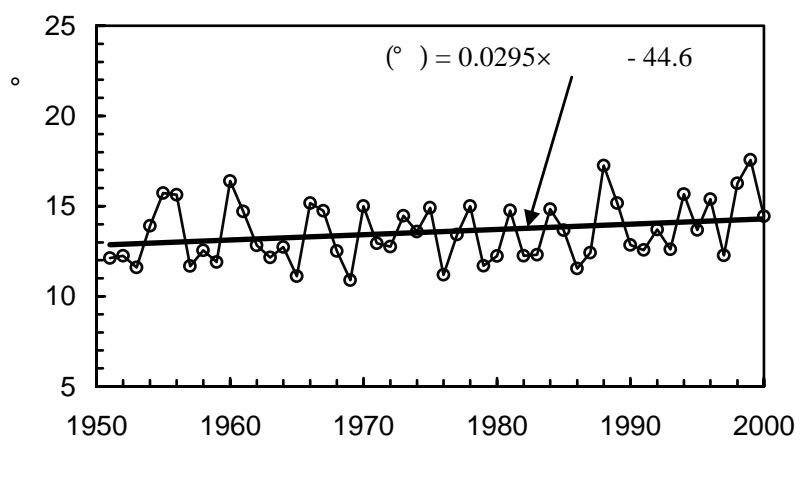

図 - 4 平均台風発生緯度の推移

図 -3 年間台風発生数の頻度分布

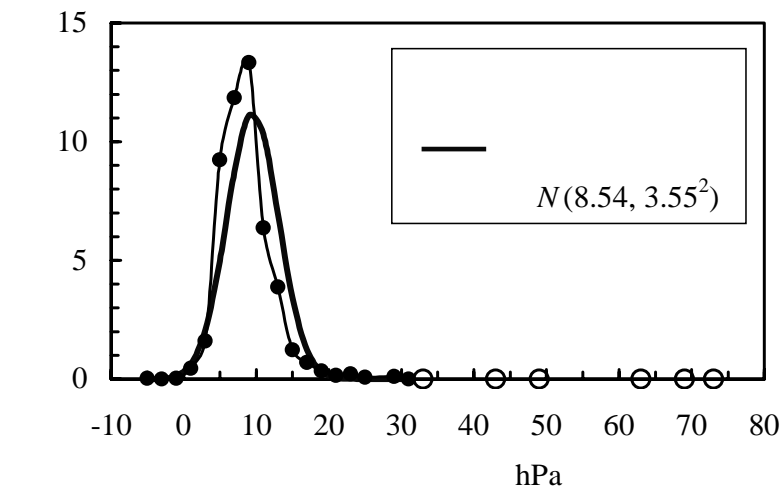

図 - 5 台風発生時の中心気圧低下量の分布 


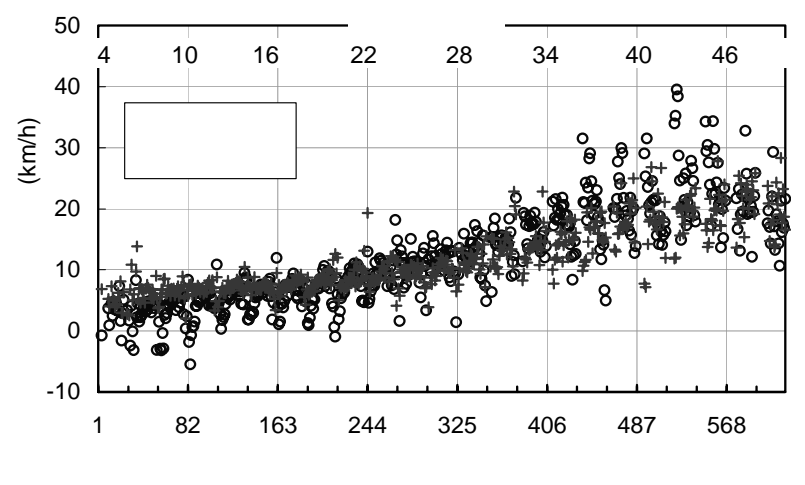

(1)南北移動速度

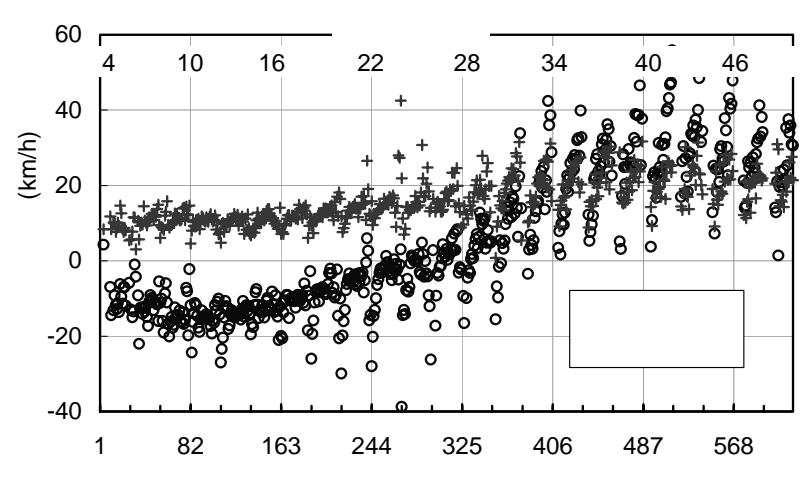

(2) 東西移動速度

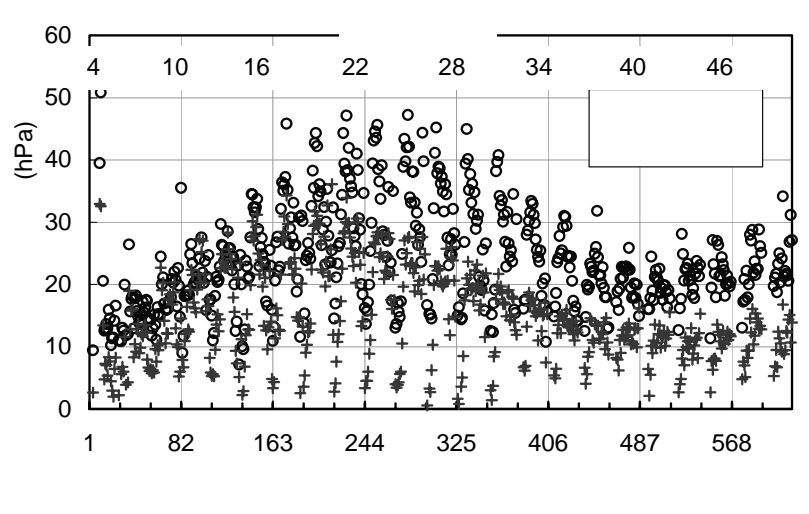

(3)中心気圧低下量

図-6 各解析格子における南北, 東西移動速度, 中心気圧低下量の平均値と標準偏差

\section{3 台風移動時の特性}

既に述べたように,本シミュレーシシンでは光田, 藤井 の手法 ${ }^{9}$ と同樣に台風中心の南北 緯度方向), 東西 経度方向)移動速度および中心気圧低下量のろのパ ラメターが,現時点と 6 時間後の值に次のような線形関 係があると仮定している.式 (1)は既往の研究 ${ }^{9,11)}$ で用 いられているものと同形式であるが,式 (2) は海面水温 の影響を考慮するために新たに海面水温項 \$ST)を導 入したものである.海面水温は，2.2で述べたように台 風強度に対して正の相関を持ち,一般には非線形の効 果を持つが,式 (1) と同形式にすることで簡便さを考慮し た.また, 移動速度に与える海面水温の影響は確かめら
れていないが ,ここでは中心気圧低下量と同形式で考え た。

$$
\begin{aligned}
& X_{\text {new }}=a X_{\text {old }}+b+e \\
& X_{\text {new }}=a X_{\text {old }}+b \cdot \mathrm{SST}+c+e
\end{aligned}
$$

ここで, $X_{n e w}: 6$ 時間後の値， $X_{\text {old }}$ 現時点での值， $\mathrm{SST}$ 海面水温, $a, b, c$ :回帰係数, $e$ 誤差 .

回帰係数は,1951〜2000 年までの 6 時間毎に記録さ れた台風統計データ移動速度 北, 東向きを正,中心 気圧低下量) と每面水温データをもとに，各解析格子毎 に求めた .海面水温デー多は, 気象庁が作成した 1950 年 1 月上旬〜2000年 12 月下旬までの北西太平洋域 北 緯 $0 \sim 60^{\circ}$,東経 $100 〜 180^{\circ}$ )の緯経度 $1^{\circ}$ メシシシュの 旬平均海面水温格子点値であり,このうちの平年値 過 去 30 年の平均値)の 6〜10 月の值を平均したものを用 いた.これは,台風の発生, 発達が活発になる時期での 海面水温との関係を見るのが好ましいと考えたためであ る.

図－7に一例として，(1)北緯 $18 〜 20^{\circ}$,東経 138〜 $141^{\circ}$ と (2)北緯 $28 \sim 30^{\circ}$, 東経 $129 \sim 131^{\circ}$ の解析格 子における回帰分析結果を示す.いずれも海面水温を 考慮していない単相関解析の例であるが，(1)の台風発 生頻度の高い地点では特に南北移動速度に関する相 関が比較的悪いが，(2)の転向点を過ぎた地点では相 関係数も上昇することが判る. (1)，(2)とも正の相関を 持ち,線形回帰式でうま〈表現できることを示している.ま た，図－8に海面水温を考慮しない場合 武 ())，考慮 した場合 武 \&))のすべての解析格子における回帰係 数 $a, b, c$ を示す.なお，いずれのケースにおいても,係 数 $a$ が 0 となる格子は陸上であり,この点については周 辺格子から補間を行うとで対応した。

まず,海面水温を考慮しない式 (1)の場合は，南北， 東西移動速度において低緯度で $a$ が相対的に小さく， 転向点あたりで最大となる.南北移動速度では,転向点 を過ぎてからの $b$ がきなばらつきを示すようこなり,多く の台風がこの領域で加速していくことを示している.また， 東西移動速度の $b$ は負から正に転してており,西から東へ と台風か転向する特性をよく表している.一方, 中心気 圧低下量については, 低緯度地域で $a$ が大きく, $b$ も転 向点よりも少し低緯度で最大となる傾向にあることから， このあたりで台風が最も成長する樣子を表している.

次に,海面水温を考慮した式 (2)の場合を見ると,南 北, 東西移動速度では, 低緯度で $a$ か相対的に小さく, $b$ の絶対值が大きい 南北移動速で正, 東西移動速度で 負）.これは,転向点あたりまで每面水温の影響によって 南北移動速度は次第に大きくなり, 東西移動速度は $b$ が 負であることにより西に向〈が, 弚の後東へ転向すること を示している.また，中心気圧低下量では，低緯度で $a>$ $1, b>0$ であることより,海面水温の影響を受けて中心気 圧が低下していくことを示している.なお，海面水温を考 慮しない場合 (1)-(iv)) と違い, 図において転向点が明 確でないのは, 海面水温項 \$ST) か溉ね 20〜30Cのレ ベルであるため, $b \square S S T$ と $c$ の影響度が相殺されたため と考えられる。

また ,図 - 9に海面水温の考慮あり,なしにおける回 
帰係数の算出過程での 重)相関係数を比較した.これ より,温度項を考慮したほ功，わずかに相関が上昇す ることが判る.このことより，海面水温を考慮しても既往の シミュレーション手法と同程度かとれ以上の精度でシミュ レーションが可能であることを示しており,海面水温の影 響を台風シミュレーションで考慮できることになる.なお， 相関が低い格子は,両ケースともデー多数の少ない格子
であり，解析領域の端格子の割合が高かつた .この格子 による解析精度への影響は,台風の通過数が少ないこと から低いと考えられる.また，中心気圧低下量に関して は海面水温の考慮にかかわらずかなり店い相関を示し ているが,台風移動速度に関しては相関の低い格子も 多〈あり,今後の検討が必要と考えられる。
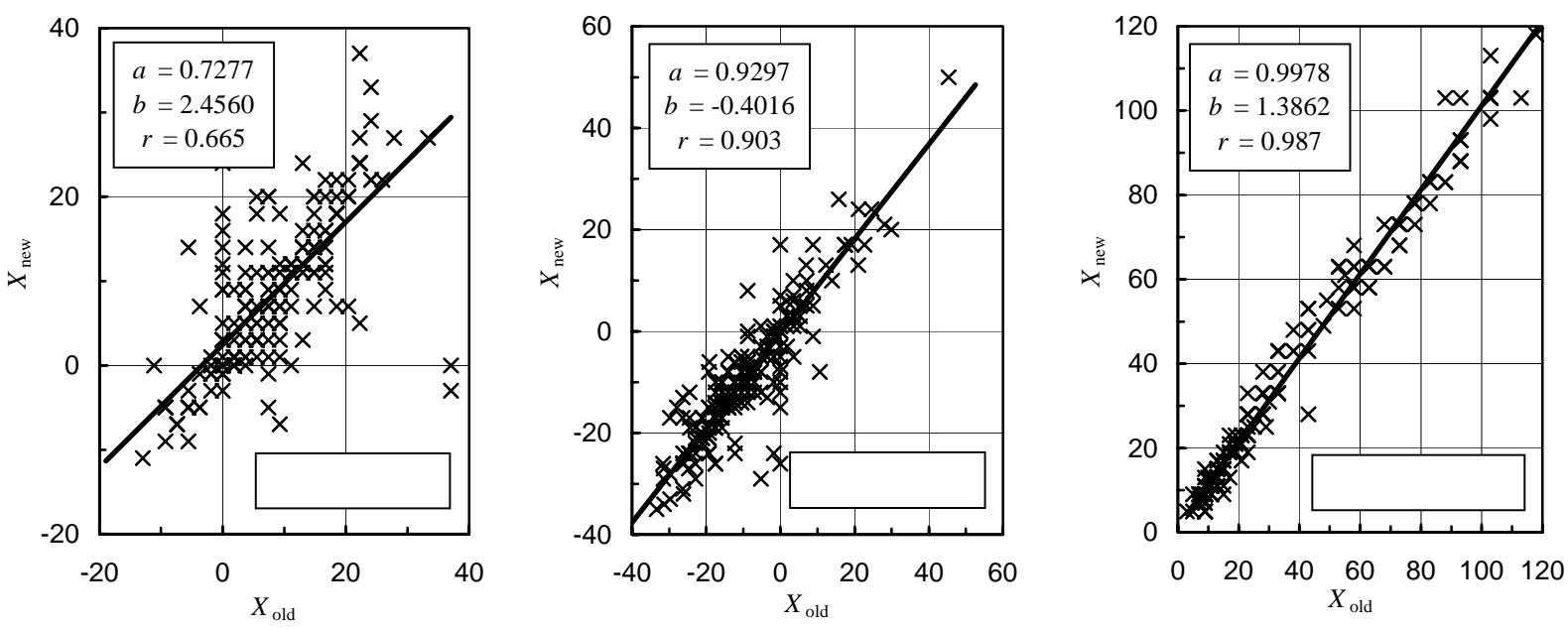

1) 北緯 18～20 ,東経 138～141 ${ }^{\circ}$
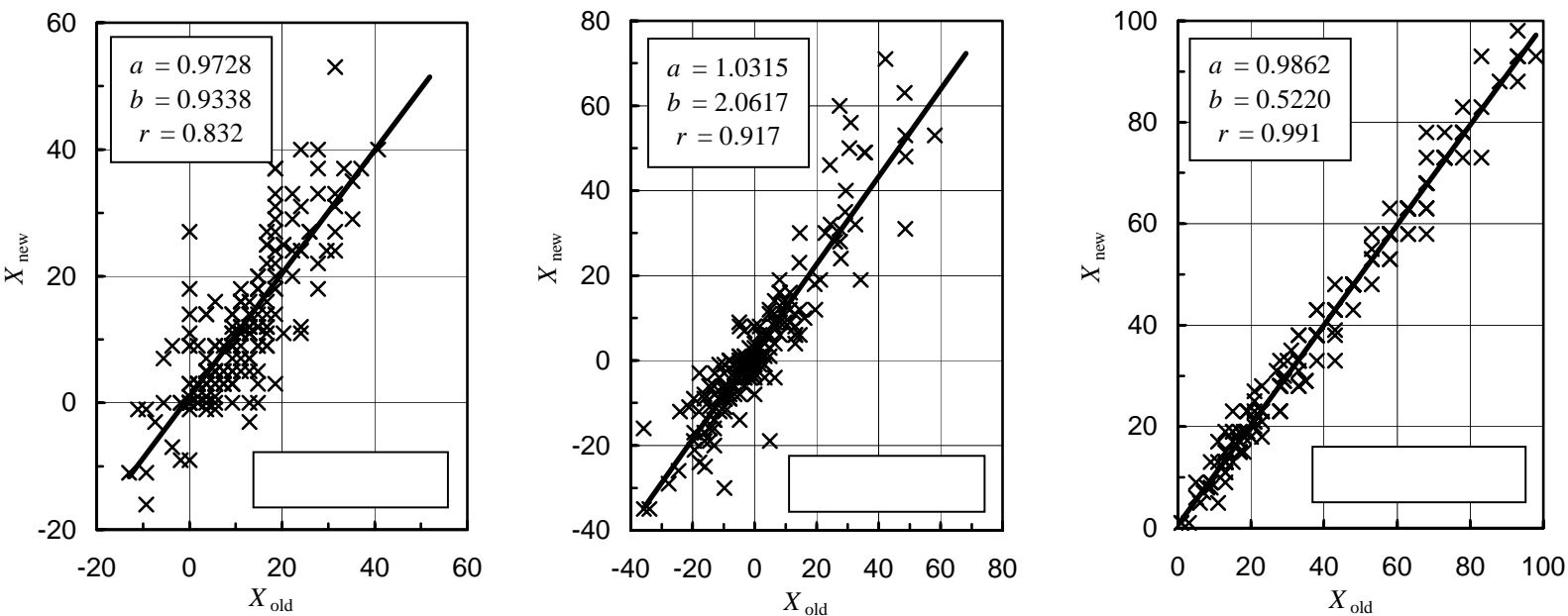

\&)北緯 28～30 ,東経 129～131 。

図 - 7 各パラメターの現在と6 時間後の関係 


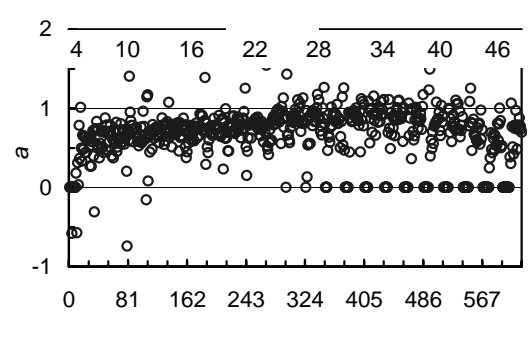

i) 南北移動速度, $a$

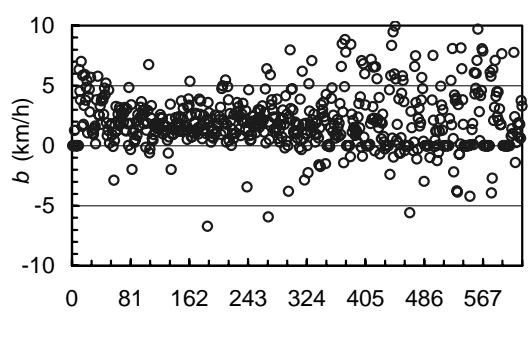

(i) 南北移動速度, $b$

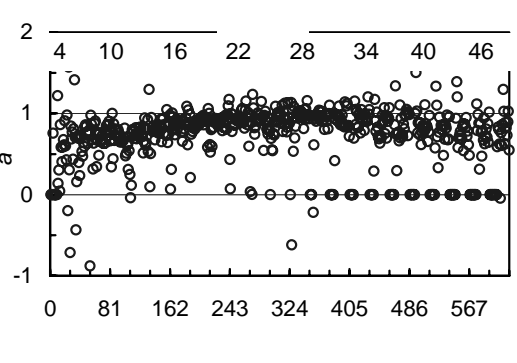

(ii) 東西移動速度, $a$

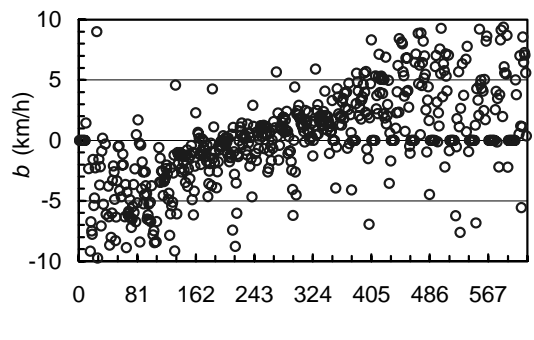

iv) 東西移動速度 , $b$

(1)海面水温考慮なし

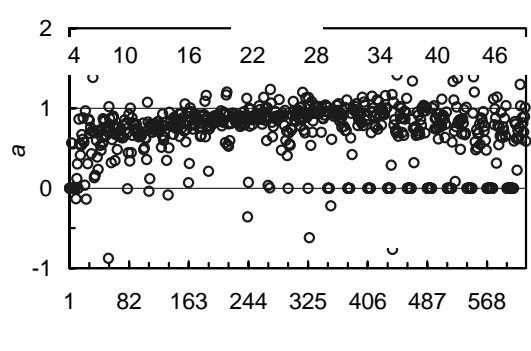

(v) 東西移動速度, $a$

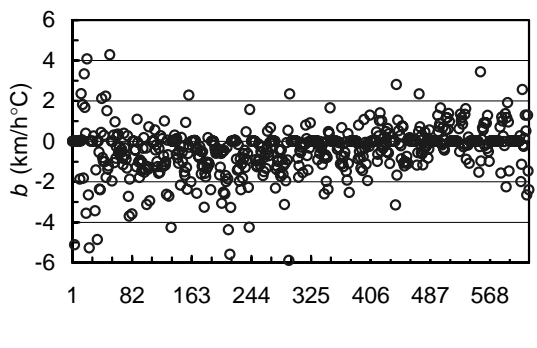

() 東西移動速度, $b$

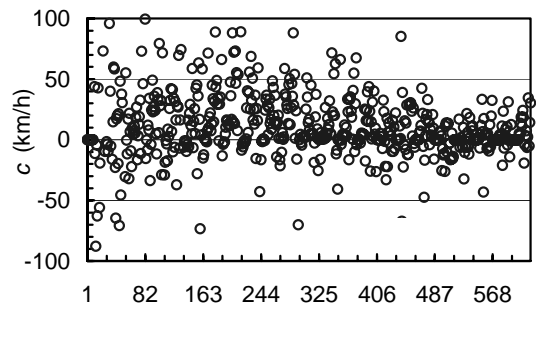

(i) 東西移動速度, $c$

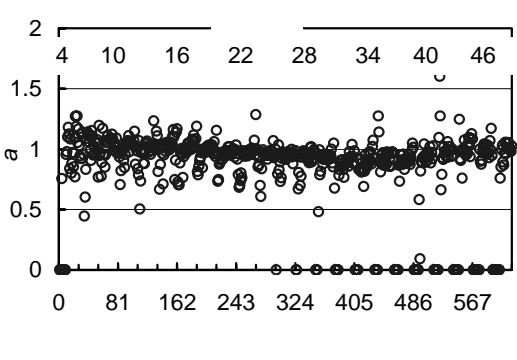

や) 中心気圧低下量 , $a$

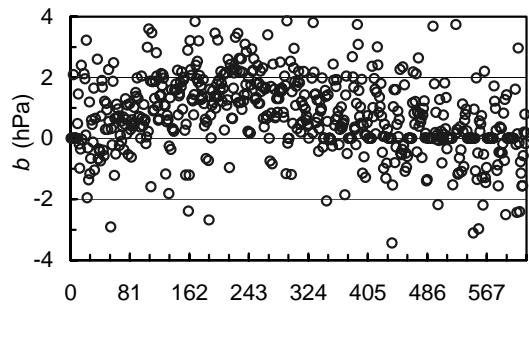

(ii) 中心気圧低下量, $b$

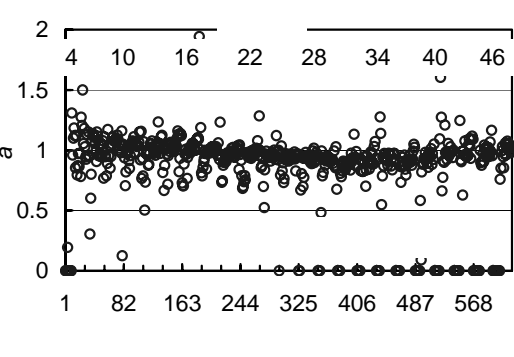

fii）中心気圧低下量 , $a$

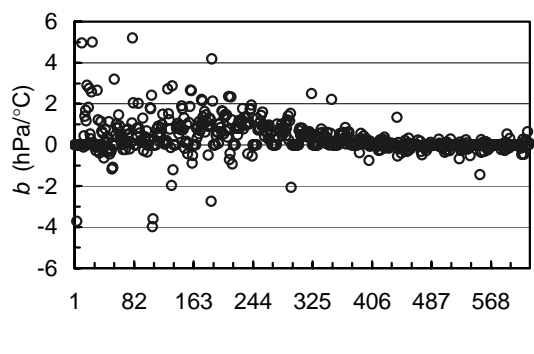

(jiii) 中心気圧低下量,$b$

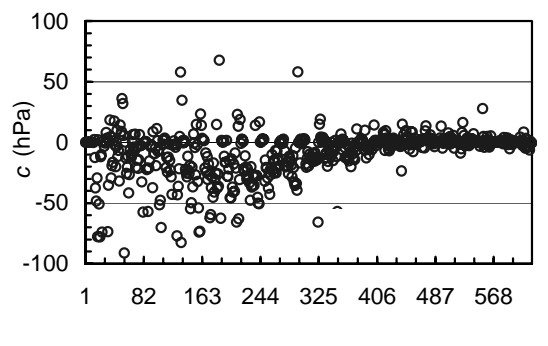

i(x) 中心気圧低下量, $c$

(2)海面水温考慮

図 - 8 線形回帰式における各パラメ久ーの值 


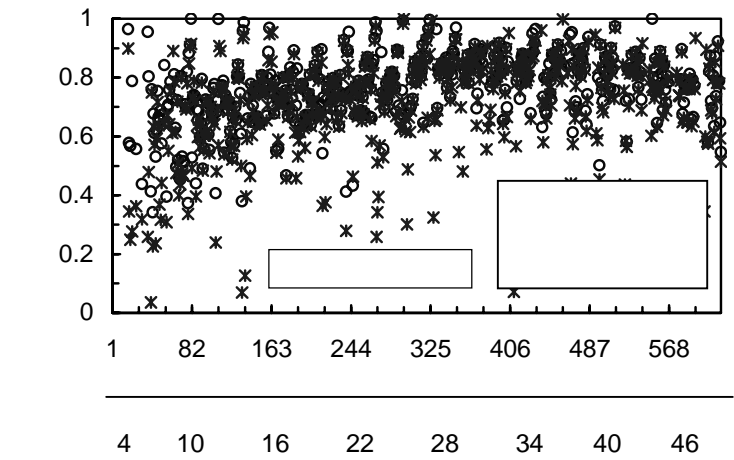

(1) 南北移動速度

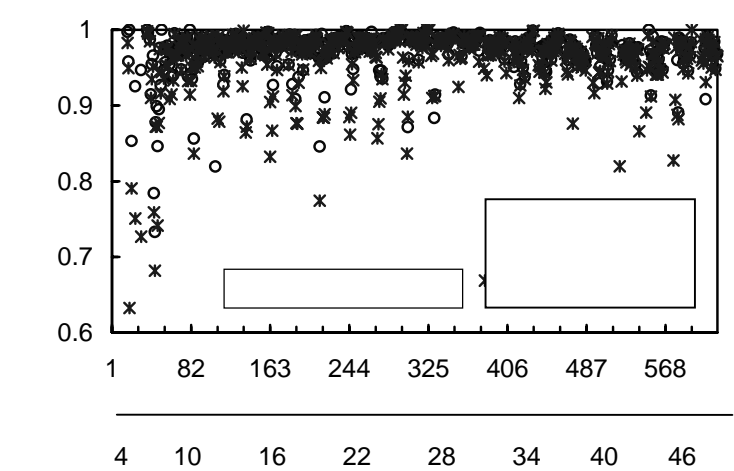

(3) 中心気圧低下量

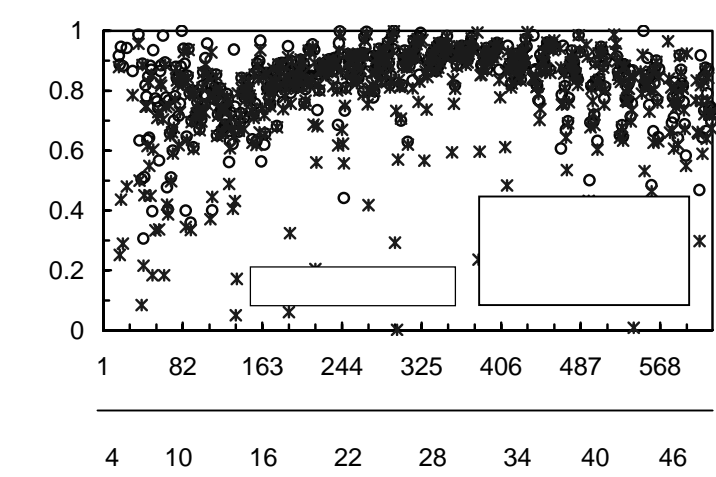

(2) 東西移動速度

重)相関係数の全格子平均

\begin{tabular}{|c|c|c|}
\hline & 温度項なし & 温度項あり \\
\hline 南北移動速度 & 0.724 & 0.764 \\
\hline 東西移動速度 & 0.789 & 0.830 \\
\hline 中心気圧低下量 & 0.958 & 0.972 \\
\hline
\end{tabular}

図 - 9 線形回帰式算出にお(る 重)相関係数

\section{4 台風強風場のモデル}

台風シミュレーションでは,台風の中心気圧低下量， すなわち中心気圧と移動速度が得られる.次に，中心気 圧低下量をもとに台風内の気圧場を求め, 台風中心と 着目点までの距離から風速を算出することが出来る.

台風内の気圧場，すなわち気圧分布を表すものとし て，等圧線が同心円状に分布しているとい弾純な気圧 分布型でパラメター数が出来るだけ少なく,かつ現実の 気圧分布によく適合するものとして, 本研究では次に示 す Schloemer の式を用いた .

$$
P=P_{c}+\Delta P \exp (-1 / x)
$$

ここで, $x=r / r_{m}$ k:台風中心からの距離， $r_{m}$ 最大旋 衡風速半径) , $P_{c}$ :中心気圧, $\Delta P$ :中心気圧低下量であ る.

次に,気圧分布から台風内の風速分布を算出するに あたっては ,Yoshizumi の方法 ${ }^{21)}$ をいることとした .こ れは,台風の中心と共に移動する座標系を考え, 弚こに おいて定常な気圧場と風の場が傾度風バランスしている 状態を想定するものである.

図 - 100よう台風中心が速度 $C$ て移動する座標系 では ,流線の曲率を $K_{s}$ として ,流線方向および流線の法 線方向の力のつり合いを考えることで,台風中心に対す る相対風速 $V$ か以下にようこ求められる.

$$
V=\frac{f}{2 K_{s}}\left(-1+\sqrt{1+\frac{4 K_{s}}{f^{2}}\left(\frac{1}{\rho} \frac{\partial P}{\partial r} \cos \beta-f C \cos (\theta+\beta)\right)}\right)
$$

ここで,fはコリオリ゚ララメー,及は流線が等圧線を横切
る角 内向きを正)であり次式で与えられる。

$$
\tan \beta=\frac{f C \sin \theta}{\left(\frac{1}{\rho} \frac{\partial P}{\partial r}-f C \cos \theta\right)}
$$

また，流線の曲率 $K_{s}$ は,式 \$) と式 \$)の $\theta$ に関する微 分とから次のよう表せる.

$$
K_{s}=\frac{1}{r} \cdot \frac{1+A^{2}-2 A \cos \theta+A^{2} B \sin \theta}{\left(1+A^{2}-2 A \cos \theta\right)^{\frac{3}{2}}}
$$

ここで , $A=\frac{C}{(1+E) V_{g r}}, B=\frac{(1+2 E)(S-E)}{(1+E) E}, E=\frac{V_{g r}}{f r}$, $S=\frac{1}{f} \frac{\partial V_{g r}}{\partial r}$ である.

傾度風 $V_{g r}$ についても図 - 11に示す力の釣り合を考 えることで以下のようこ求められる.

$$
V_{g r}=\frac{f r}{2}\left(-1+\sqrt{1+\frac{4}{f^{2} r} \cdot \frac{1}{\rho} \frac{\partial P}{\partial r}}\right)
$$

地球に固定した座標系における台風域内の風速は式 4)により求まる移動座標系における摩擦を無視した風 速 $V$ と台風の中心の移動速度 $C$ をべクトル的に加えたも のに等しい.これを $\overrightarrow{V_{e}}$ とすると，

$$
\overrightarrow{V_{e}}=\vec{V}+\vec{C}
$$

である.ただし,式 8)で求まる $\vec{V}_{e}$ は上空風 摩擦を無 視した風)である。 


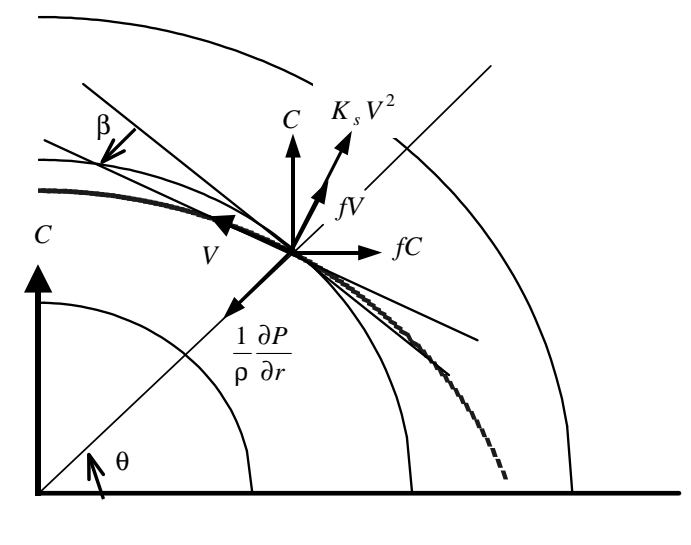

図 - 10 移動座標系における風速バランス

台風内の上空風速と $10 \mathrm{~m}$ 高さでの地上風速 $V_{10}$ との 関係については，観測例も少なく不明な点が多いが ,一 般に海上においては $V_{10}=\frac{2}{3} V_{e}$,地上では $V_{10}=\frac{1}{2} V_{e}$ で 表されると言われている.また，道路橋耐風設計便覧 ${ }^{22)}$ の粗度区分 IIにおて,上空風速と地上風速 $V_{10}$ の関 係か約 1/2 となることも考えて, 本研究では, 島しd部 後 て述べる,石垣島，那覇，小笠原，八丈島)で

$$
V_{10}=\frac{2}{3} V_{e}
$$

その他の地域で

$$
V_{10}=\frac{1}{2} V_{e}
$$

とした .

ところで,式 4)で与えられる風速 $V$ および式 ๆ)の傾 度風速 $V_{g r}$ を求める際に台風内の気圧勾配 $\partial P / \partial r$ が必 要となるが, 二れは最大旋衡風速半径 $r_{m}$ を決め,式 $\left.\beta\right)$ による気圧分布式を使うことで求められる.このとき， $r_{m}$ は， 台風データ及び,気象官署で測定された海面気圧より, 先の Schloemer の気圧分布式を用いて回帰的に求める ことができる.安井らは 1951〜1995 年の間に発生した台 風を対象とし， $r_{m}$ を求めた ${ }^{11)}$.二れによると, $\Delta P$ が大きい ほど $r_{m}$ は小さ〈なる傾向があり, $\Delta P$ が小さいほど $r_{m}$ のば らつきが大きくなることを調べた .また,$r_{m}$ の平均値 $\mu_{r_{m}}$, 標準偏差 $\sigma_{r_{m}}$ は, $\Delta P$ のべき指数関数で近似でき,乥れ

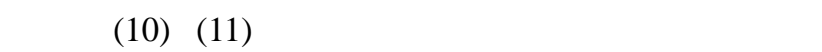
ては,使用した台風データがほぼ同じ 本研究では 1951 〜2000 年)であることから, 安井らと同じ式を使用するこ ととした .

$$
\begin{aligned}
\mu_{r_{m}} & =2.06 \times 10^{4} \Delta P^{-1.27} \\
\sigma_{r_{m}} & =4.40 \times 10^{4} \Delta P^{-1.76}
\end{aligned}
$$

4. .台風強度特性の変化シミュレーション

4.1 シミュレーションの概要

本研究では，3.で述べた方法によって1年ごとにシミ ユレーションを行い,乥れを5000 年に相当する5000 回

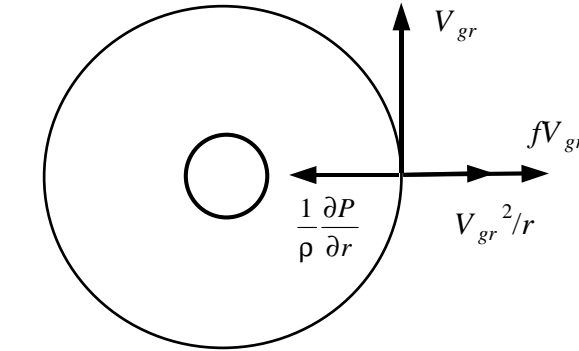

图 - 11 低気圧場における傾度風バランス

繰り返した図 - 1参照).シミュレーションは,海面水温 に現在の值を用いる゙基本シミュレーション”と将来の予 測海面水温を用いる゙比較シミュレーション゙実施した .

基本シミュレーシジに用いる海面水温としては , 3.3 で述べた気象庁発表の平年值 過去 30 年間の平均値) の 6〜10 月の旬平均海面水温を平均したものを使用し た.これは,最も海水温が高く,台風が最も発達しやす い時期と来襲最頻期を考慮したためである.

また，比較シミュレーションには，地球温暖化予測情 報 ${ }^{2)}$ の海面水温を用いた .これは，地球温暖化の影響を 評価することを目的とし,気象庁気象研究所で開発した 大気 海洋結合大循環モデルを用いて今後 150 年間に わたる全球気候予測の数值実験を行ったものである.予 測値には, 大気中の $\mathrm{CO}_{2}$ 濃度か将来に渡って一定とし た基準実験と, $\mathrm{CO}_{2}$ 濃度力腹利的に $1 \%$ ずつ増えていく 漸増実験とがあるが,本研究では, 将来動向が不確定 であることも踏まえ，比較的緩やかに温暖化が進行する 基準実験での将来海面水温予測值を使った .なお，基 準実験では,日本南海において今後 100 年間で最大 3 $\sim 4^{\circ} \mathrm{C}$ 海面水温の上昇が見込まれている.以下のシミ ユレーションでは,基準実験での予測年次にあわせて， 40 年後, 80 年後の海面水温を用い, 2 ケースの比較シミ ユレーシシンを実施した.図 - 12に基本シミュレーショ， 比較シミュレーションで用いた海面水温を示す.これによ ると,比較シミュレーシシンにおける 40 年後, 80 年後の海 面水温は,現在值と比較して台風力発達する北緯 30 度 以南で毞れ毞れ平均 $0.8^{\circ} \mathrm{C}, 1.1^{\circ} \mathrm{C}$ 程度上昇している.さ らに, 海面水温パラメ久ーの取り込み方に着目して, 以 下の3種類の条件でシミュレーションを実施した .

\section{(1)シミュレーション| (im と表記)}

海面水温のパラメターを組み込まないもので,6 時間 後のパラメター值を求める際に式 (1)を用いたケースで ある.これは,基本シミュレーションに対応する \$im_ann と表記) 。

(2)シミュレーションII \$imsst と表記)

3 つのパラメター 南北, 東西移動速度, 中心気圧低 下量)の 6 時間後の予測式に,海面水温パラメターを組 み込んだ式 (2)を用いたケースである.海面水温として 現在 (jimsst_ann) と 40 年後 (jimsst_40c)，80 年後 \$imsst_80c)の3 ケースとした . 


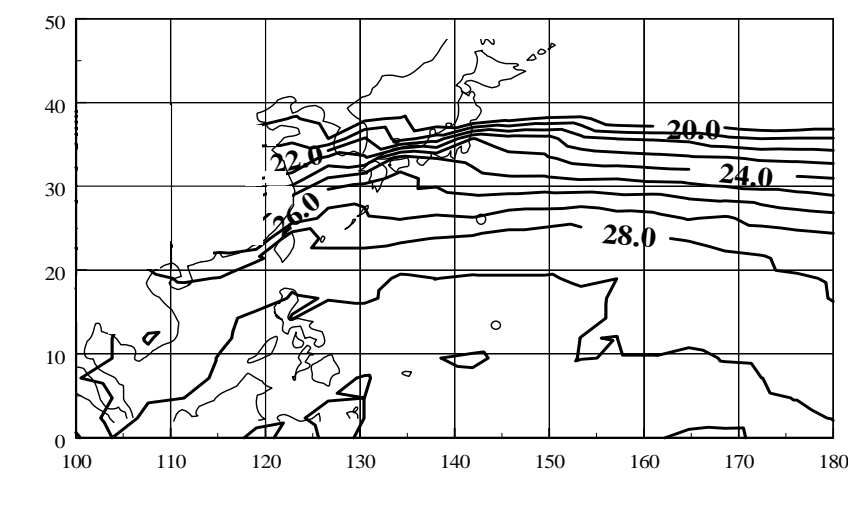

(1)平年值 9 C )

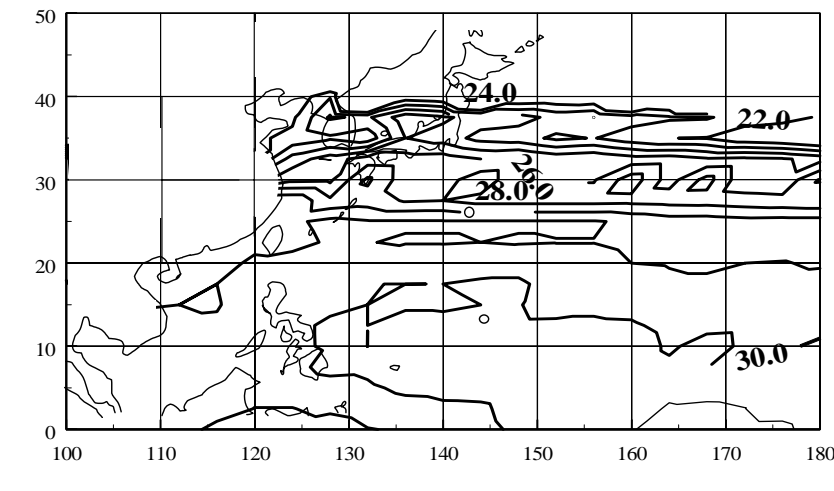

(2) 2040 年の予測值 9 )

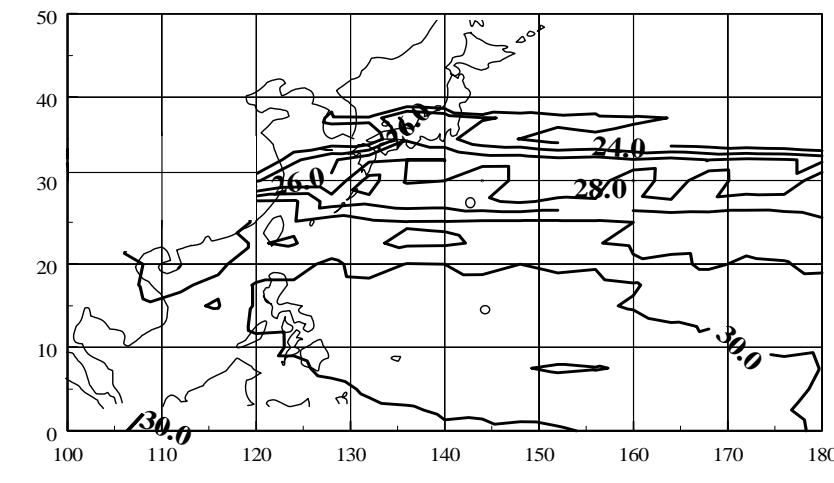

(3) 2080 年の予測值 9 )

図 - 12 台風シミュレーシジに用いた海面水温

(3)シミュレーシジIII \$imdcp と表記)

中心気圧低下量の 6 時間後の予測式にのみ海面水 温パラメータを組み込んだケースである.すなわち，移動 速度 南北,東西方向成分)の予測は式 (1)，中心気圧 低下量の予測は式 (2)を使うものである.これは,海面水 温の影響が台風強度 中心気圧低下量)にのみ相関を 持つと考えたものである.シミュレーション川と同樣に現 在 (simdcp_ann) と 40 年後 Simdcp_40c)，80 年後 \$imdcp_80c)の3 ケースをシミュレートた .

なお,本研究におけるシミュレーションでは,過去 30 年の平均值 基本シミュレーシシン)および 40 年後, 80 年 後の予測值 比較シミュレーション)を海面水温とし,100 年再現期待風速を求めている.これは, 海面水温が午れ ぞれのシミュレーショで相当期間にわたつて一定であ ると仮定していることになる.実際の海面水温は年々変 化しており特に将来の変化割合は大きい), 厳密にはこ
のことを考慮したシミュレーションの実施が求められるが， 本研究では将来の変動を予測するというよりも,むしろあ る一定の海面水温の上昇が台風強度に及ぼす影響を 検討することに主眼をおいている.このため，前述のよう に 40 年後, 80 年後の予測海面水温を用いてシミュレー シシコを行った。

\section{2 台風通過数の変化}

シミユレーションを行った各ケースで日本各地の台風 強度特性の変化を調べるため, 図一13に示すように 本を解析格子単位で分割し, 各領域を通過した台風の 年平均通過数を調べた.まず,現在シミュレーシシンでの 比較を図－14 (1)に示す.共通することとして,西日本と 日本南海で台風通過数が多〈なっており, 観測統計とも 対応する.また, 北海道の北, 東端で多〈なるのは, 転向 した台風の通過コースと一致するためと考えられる.海 面水温項の取闪み方に関して,台風の南北，東西移 動速度と中心気圧低下量のすべてのパラメ久ーに海面 水温項を組み込んだケース (imsst)において，南西諸 島，九州，四国および北海道での通過個数が多くなる結 果となった .また, 中心気圧低下量にのみ海面水温項を 取り込んだ simdcp_ann が海面水温項を考慮しない sim_ann とほぼ同等の結果を与えていることから，海面水 温の影響を取り込んだシミュレーシシによよて将来の変 化を予測する場合には,中心気圧低下量にのみに海面 水温項を取り込んだ手法が妥当であると考えられる.な お，海面水温項の取り込み方の違いによる結果の相違 については,今後の検討が必要である.

次に，現在と将来の比較を図 - 14 (2)，(3)に示す。 (2)はシミュレーションII jimsst)に，また (3)はシミュレ

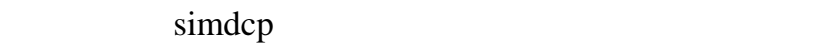
のパラメター全てに取に込むか, 中心気圧低下量にのみ 取闪むかの違いである.これより，一部の地域 北海道 の一部と小笠原)を除いて，海面水温の上昇に伴って将 来の台風の通過個数力増加することとなる.特に, 海面 水温を中心気圧低下量にのみ取り込んだ simdcpのケー スにおいて ,光の増加割合が大きくなっている.

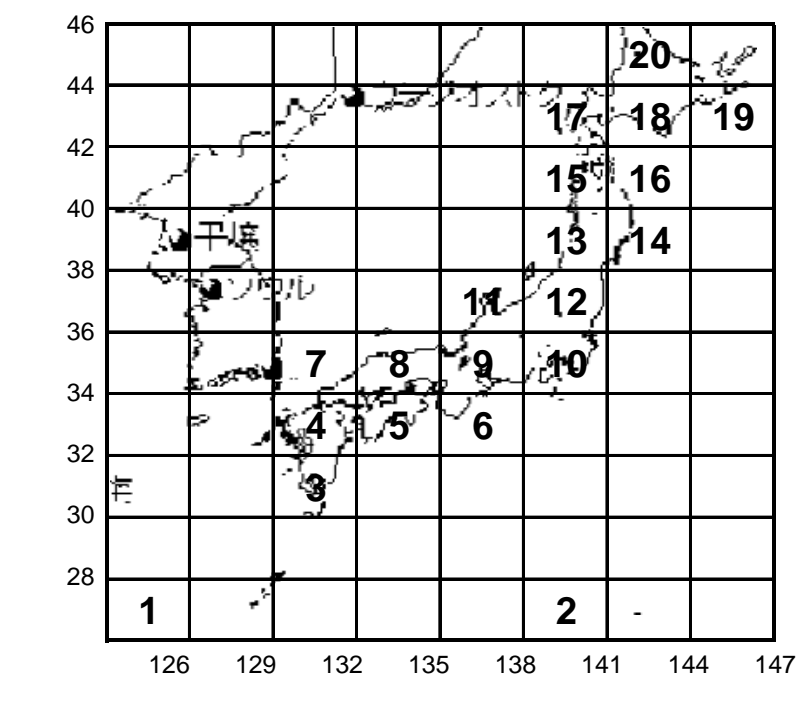

図 - 13 台風強度特性の変化を検討する領域 $(〜 20)$ 
また，図－14 (4)，(5)に 40 年後, 80 年後に相当する 海面水温まで上昇した場合の台風通過数の現在との比 を示す．(4)は 3 つのパラ双一に海面水温項を考慮し たケース，(5)は中心気圧のみに海面水温項を考慮した ケースである. (4)では地域間のばらつきが多く,特に小 笠原, 北海道東部て将来の台風通過数が減少するが, 他の地域ではほほ増加しており,特に東北地方で増加
割合が大きい.また, (5)では各地域とも一樣の増加傾 向を示した。(1)で示されたよう海面水温項の考慮は， 中心気圧低下量にのみ取り込んだケース (imdcp)が妥 当であるとするならば, 40 年後, 80 年後に相当する海面 水温の上昇によって关れ光れ現在よりも 1.5 倍強, 2 倍近 くに台風通過数か増えることが予測される.

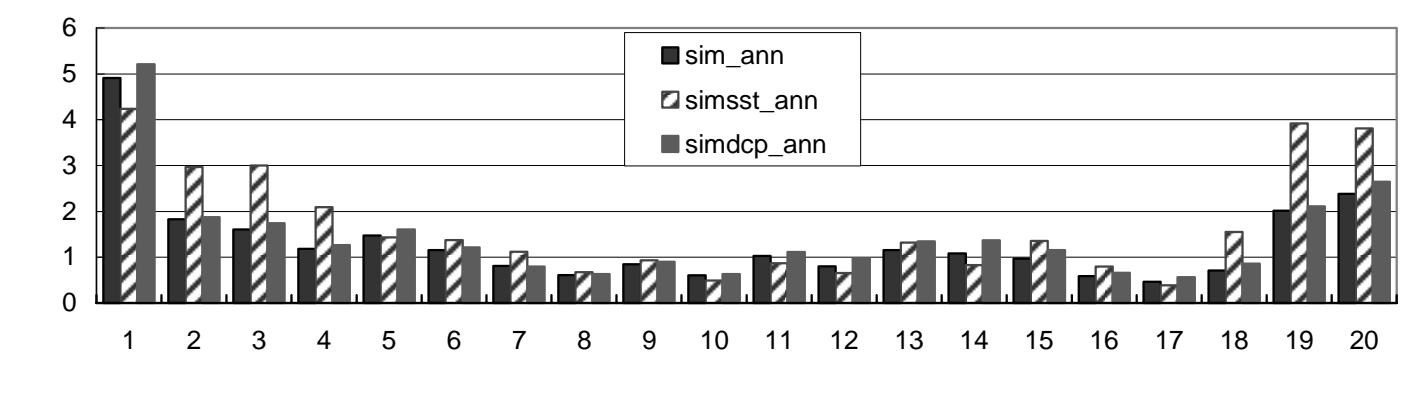

(1)現在シミュレーシジ (nn)

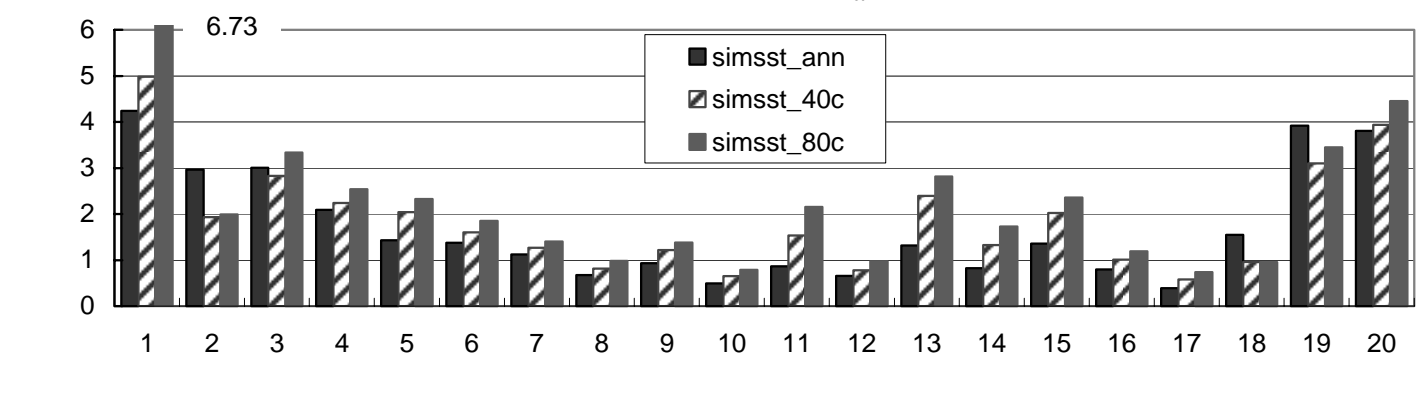

(2)シミユレーションII (imsst)での将来変化

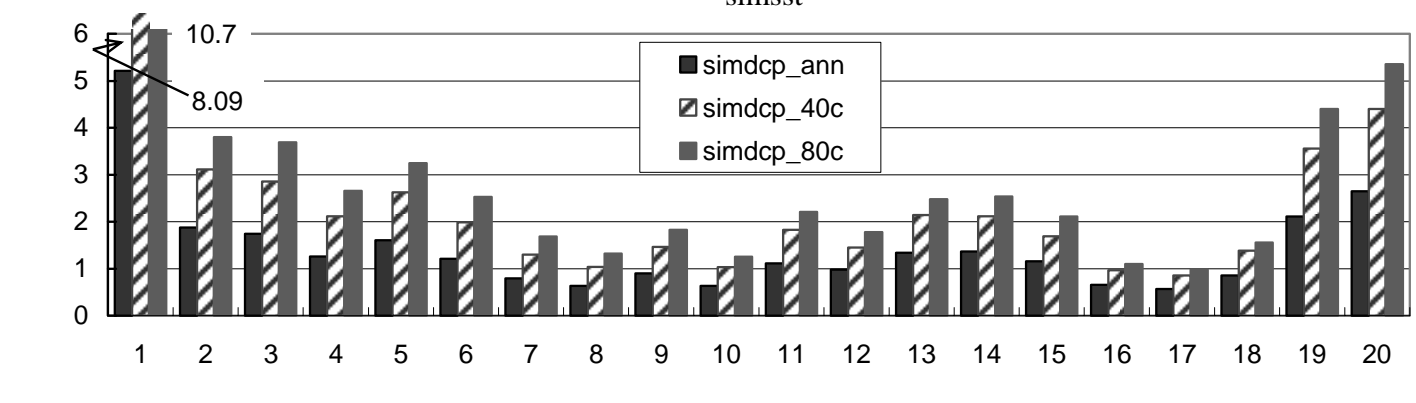

(3)シミユレーションIII (imdcp)での将来変化

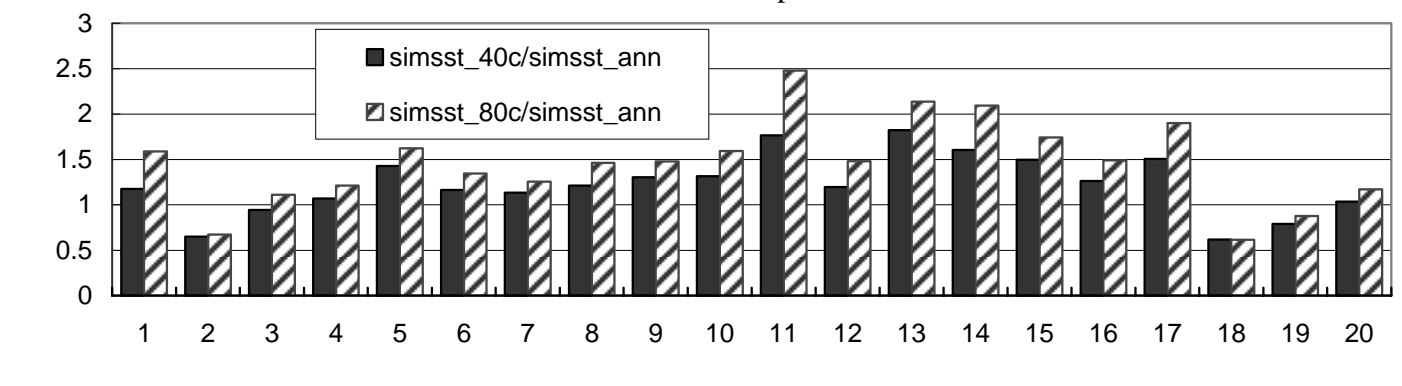

(4)シミユレーシシンII での現在と将来の比

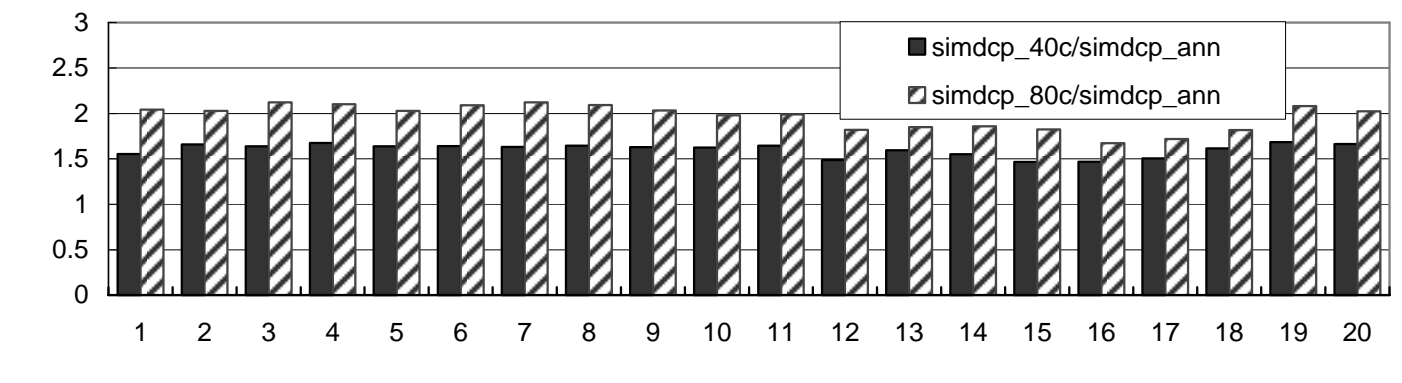

(5) シミユレーションIIIでの現在と将来の比

図 - 14 年平均台風通過数の比較 
4.3 中心気圧低下量の変化

台風通過数の将来変化と同樣に,台風の中心気圧低 下量の将来変化について調べた.図 - 15には,図-1 ろに示す各領域を通過した台風の年最大中心気圧低下 量の 99 パーセンタイル值 100 年再現期待値に相当. 以 下, $99 \%$ 中心気圧低下量という)の 40 年後, 80 年後に相 当する海面水温に上昇したケースと現在との比を示す．

(1)，(2)は光れ光れ海面水温項をすべてのパラメター に考慮するか, 中心気圧低下量にのみ考慮するかの違 いである.地域の違いによる差は両方で同樣の傾向にあ るが，(2)の中心気圧低下量にのみ海面水温項を考慮 した場合の方が将来の中心気圧低下量の増大が大きく
なっている.日本南海，九州，四国，関東以西の本州， 北海道東部で将来の中心気圧低下量の期待值が $50 \%$ 程度以上増大するが,東北, 北海道南西部では逆に減 少する結果となた。

以上のことから,地球温暖化の進行に伴海面水温の 上昇によって, 将来は日本南海, 関東以西および北海 道東部において期待される中心気圧低下量の増大が予 想されることとなる.乥して, 海面水温項を中心気圧低下 量にのみ取り込んだシミュレーシジIII (imdcp)によると， $99 \%$ 中心気圧低下量が全地域の平均で 40 年後, 80 年 後に相当する海面水温上昇によって現在よりも关れぞれ $36 \%, 51 \%$ 増大することとなる。

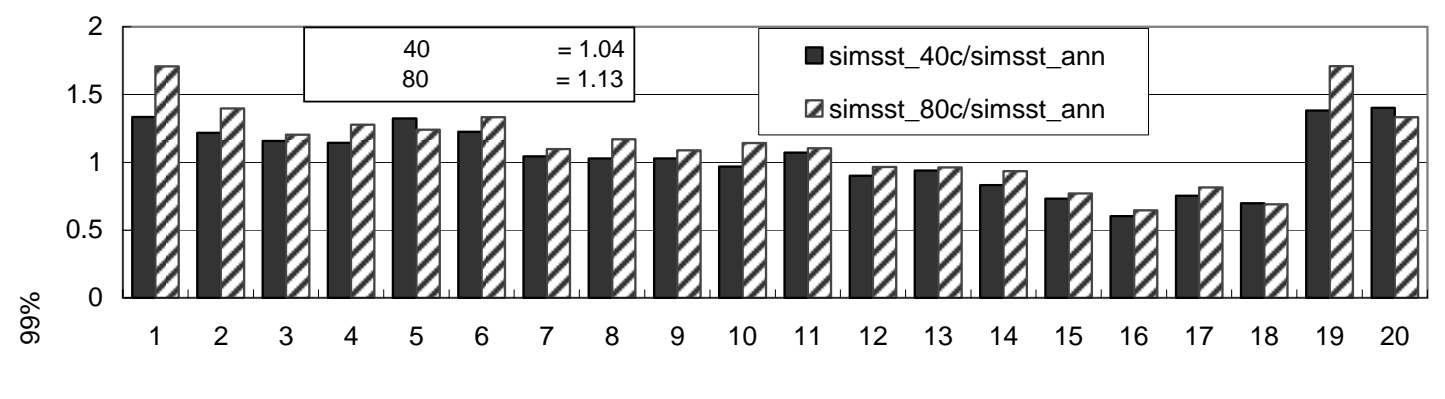

(1)シミュレーション川での現在と将来の比

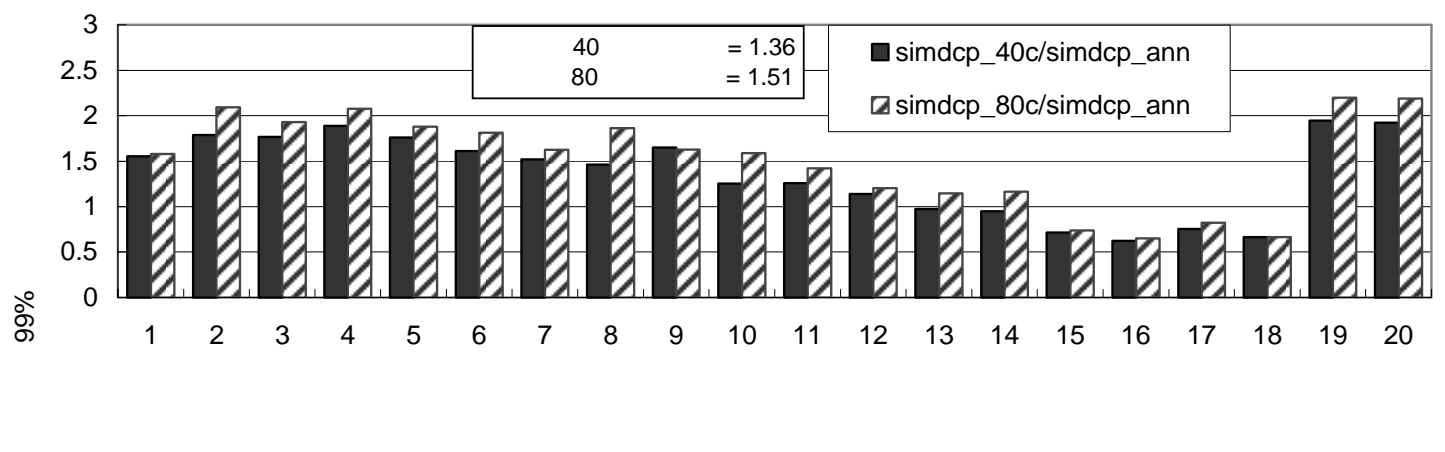

図 - 15 年最大中心気圧低下量の 99 パーセンタイル值の比較

\section{4 再現期待風速の変化}

海面水温の影響を考慮したシミュレーシジによって， 海面水温および光の変化が各地点の再現期待風速に 与えろ影響について検討を行つた .まず,図－1に示す ように,シミュレーションによって発生した台風特性をもと に,対象とする地点から $200 \mathrm{~km}$ 以内に接近した台風に ついて，3.4で述べた方法によって風速を求めた。光し て,これを繰り返すことで年最大風速を求め，光れを極 值Ｉ型分布に適合させることで再現期待風速を求めた . なお，極值 I 型へのプロッ法としては,ハーゼンの方法 を用いた.対象とした地点は, 根室, 新潟, 大洗, 勝浦, 東京,八丈島, 小笠原, 小田原, 御前崎, 名古屋, 津, 大阪,和歌山, 松江, 広島,山口, 高松,室戶, 福岡, 長 崎, 宮崎, 鹿児島, 那覇, 石垣島の 24 地点である。

炎のうち, 根室, 東京, 八丈島, 高松, 鹿児島, 那覇 の年最大風速の極值 I 型分布へのプロットを図 - 16に 示す.いずれの地点でも両裾を除いて極值 I 型に適合 する樣子が見られる.ただし, 標準化変量が 3〜6 再現
期間 20〜 400 年に相当)あたりで累積確率か増大する傾 向と, 標準化変量が 6〜 7 再現期間 400〜1000 年に相 当) 以上で年最大風速か顗打ちになる傾向が全般的に 見られる.特に,後者の点に関しては, 今回のシミュレー ショ゙が 5000 年相当期間であることが大きな要因と考え られ，さらに長期間でのシミュレーションや多くのシミュレ ーションからのアンサンブル平均などの操作が必要と考 えられる.なお，左裾で年最大風速が 0 となるとは，台風 の影響を受けない年があるためであり, この傾向は那覇 や鹿児島よりも東京，根室のように北へ行〈ほと顕著とな る。

また，再現期待風速に与える海面水温 あるいは年の 取(込み方)の影響は，地域によって異なっている.ただ， 兴の違いは標準化変量の範囲の点で限定的であり,ま た統一的な傾向は見られない，一方，現在と海面水温 上昇ケースの違いについては顕著な差が見られるようこ なり,再現期待風速にも相当の差が見られるようになる. ただ，現在と海面水温上昇ケースとの差に比べて ,40 年 
後と 80 年後に相当する海面水温でのケースの差が光れ ほと顕著でない点については, 図 - 15に示す中心気圧 低下量と同樣である.

表 - 1には ,シミュレーシジIII \$imdcp)における各地 点の 100 年再現期待風速を比較する.再現期待風速は, 0 以外の年最大風速デー多からのモーメント法と極值 I 型プロッけ確率分布から再現期間 100 年 標準化変量 4.6)に相当する風速を読み取る方法の2つの方法で算 出した.どちらの方法でも乥れほど大きな違いがないこと が判る。また道路橋耐風設計便覧 ${ }^{22)}$, 建築物荷重指 針 ${ }^{23)}$ の風速マップから読み取った各地の 100 年再現期 待風速を併せて表一1に示す.今回のシミュレーシシンで は,再現期待值の絶対值についての議論を目的として いないが,シミュレーシシンで得られた風速は八丈島を除 いて,便覧，指針でのものと概ね対応しており,本シミュ レーションの妥当性を裏付けている.なお，八丈島につ いては,式 (9)によって上空風から地上風への換算を行 っているが ,この過程にも検討の余地があると思われる.

次に,検討対象とした 24 地点について, 年最大風速 の確率分布から求めた 40 年後, 80 年後に相当する海面 水温ケースでの 100 年再現期待風速の現在との比をシミ ユレーションII (imsst)とシミュレーションIII \$imdcp)に

ついて図 - 17に示す.ほとんどの地点で現在よりも海面 水温上昇ケースの再現期待風速が上昇することが判る が,simsst のケースでの石垣島, 那覇,山口, 福岡 40 年後)においては現在よりも海面水温上昇ケースの再現 期待風速が低下する.

全地点での増減比の平均を取ると,simsst のケースで 40 年後, 80 年後に相当する海面水温上昇によって光れ ぞれ $1.12,1.15$ となり,また simdcp のケースで先れぞれ $1.07,1.11$ となる.また，九州，四国と乥れ以外の地域に 分けると,両ケースとも九州，四国での上昇率は全国平 均よりも低く,弚の他の地点では逆に高くなっている.こ れを Emanuel の研究成果 海面水温が $+3^{\circ} \mathrm{C}$ て最大風 速が 15 20\%増大) ${ }^{15)}$ 比べると,80 年後の予測海面 水温 図-12参照)は，現在值よりも北緯 $30^{\circ}$ 以南で最 大 $2 \sim 3^{\circ} \mathrm{C}$ 程度の上昇が見られることから,概ね同樣の上 昇率が得られている。

以上のことから,地球温暖化に伴う 40 年後, 80 年後 に相当する海面水温上昇で日本各地の 100 年再現期待 風速は,地域によるばらつきはあるものの,現在よりも光 れ光れ平均的に約 $10 \%$ ，15\%弱上昇することが予想さ れる。

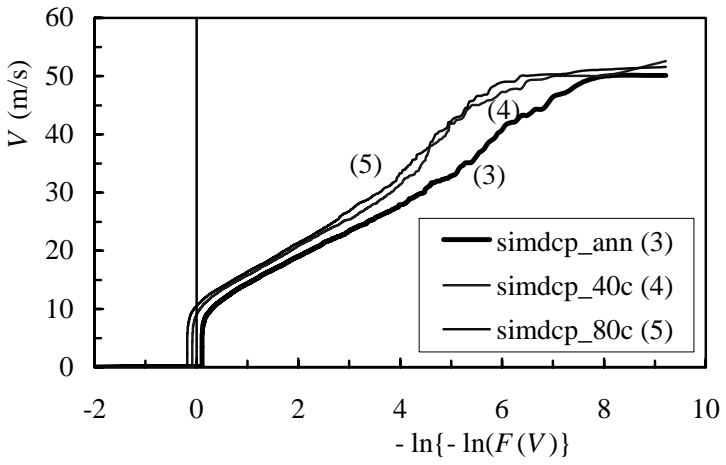

(1)根室
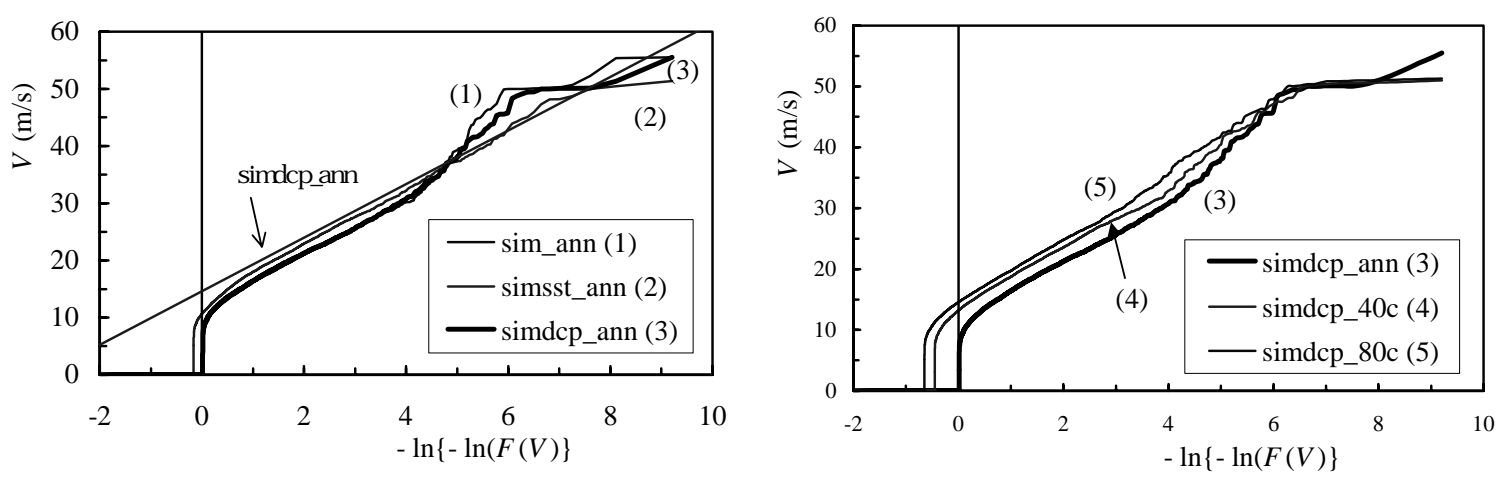

(2)東京

図 - 16 (1) 各地のシミュレートされた年最大風速の極值 I 型プロット 

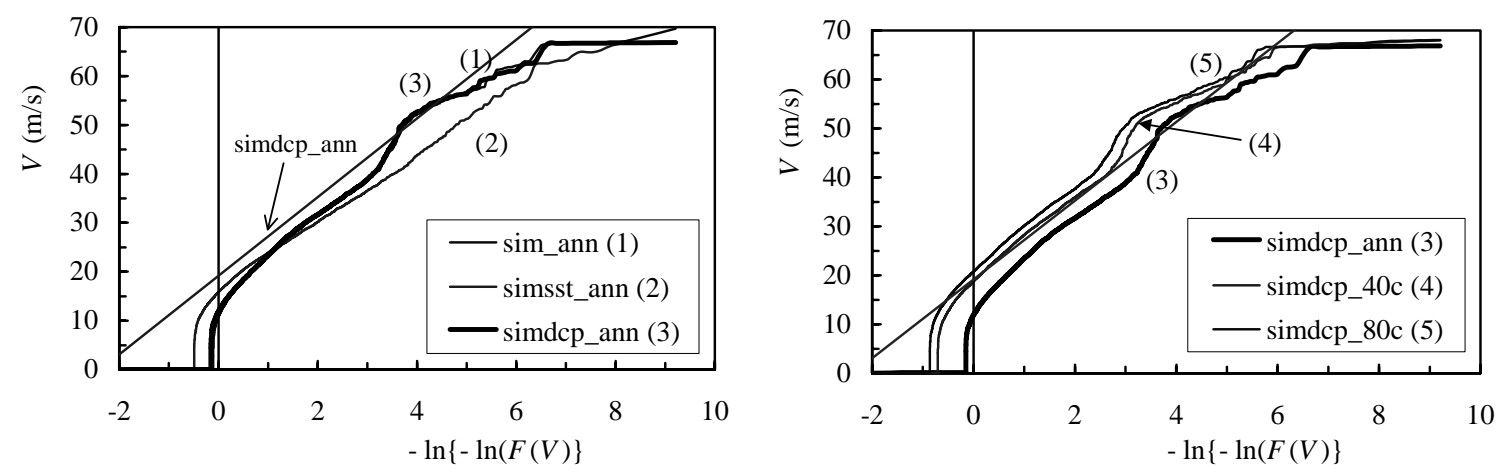

(3)八丈島
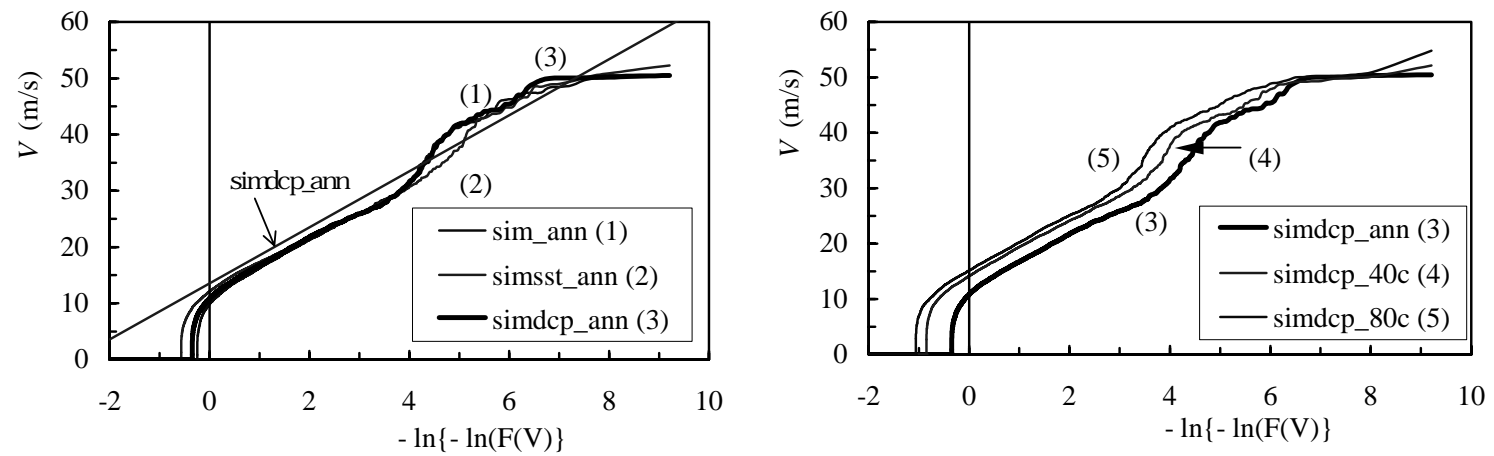

(4)高松
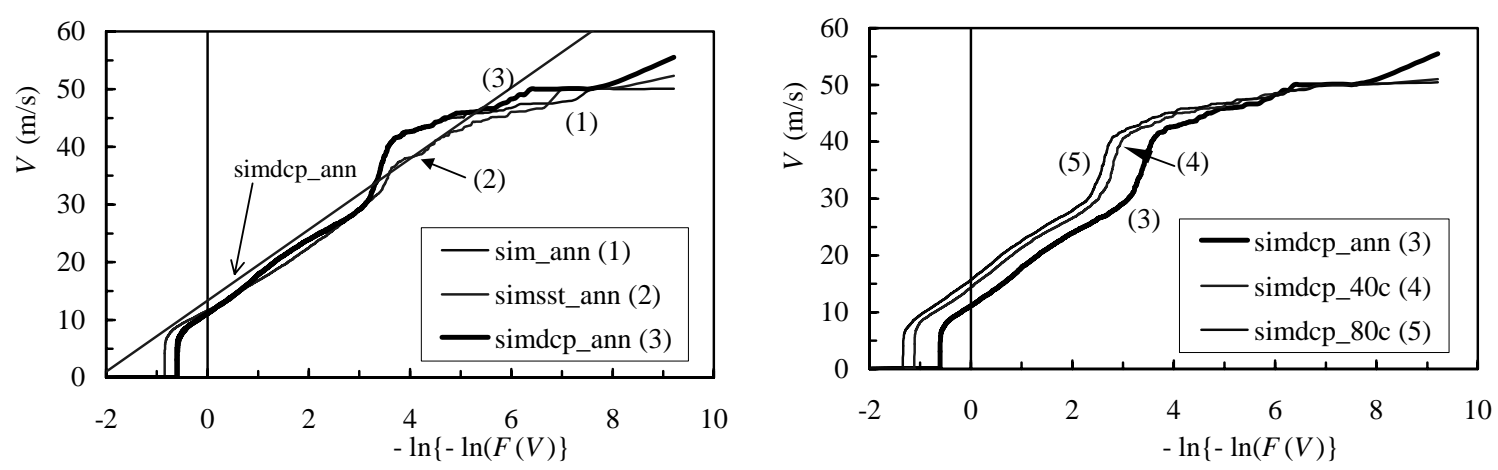

(5) 鹿児島
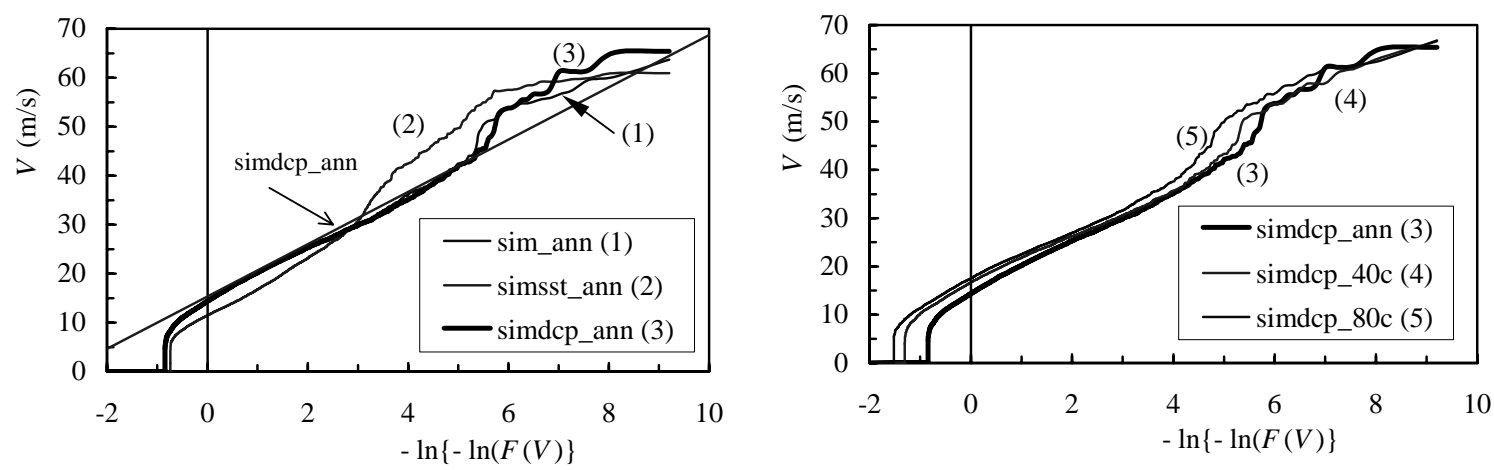

(6)那覇

图 - 16 (2) 各地のシミュレートされた年最大風速の極値 I 型プロット 
表 - 1100 年再現期待風速の比較

\begin{tabular}{|c|c|c|c|c|c|c|c|}
\hline \multicolumn{2}{|c|}{ シミュレーションIII \$imdcp) } & 根室 & 東京 & 八丈島 & 高松 & 鹿児島 & 那覇 \\
\hline \multirow{3}{*}{ モーメンド法 } & 現在 & 32.9 & 36.2 & 56.2 & 36.4 & 41.6 & 39.9 \\
\hline & 40 年後 & 36.1 & 34.5 & 59.4 & 38.5 & 45.6 & 40.3 \\
\hline & 80 年後 & 37.0 & 38.7 & 61.6 & 40.2 & 47.4 & 41.7 \\
\hline \multirow{3}{*}{ 確率分布 } & 現在 & 31.2 & 34.5 & 55.4 & 38.7 & 44.5 & 39.0 \\
\hline & 40 年後 & 38.0 & 37.5 & 57.7 & 41.7 & 45.8 & 39.8 \\
\hline & 80 年後 & 38.4 & 39.6 & 58.8 & 43.6 & 46.2 & 43.6 \\
\hline \multicolumn{2}{|c|}{ 道路橋耐風設計便覧 ${ }^{22)}$} & 30 & 35 & 45 & 35 & 45 & 45 \\
\hline \multicolumn{2}{|c|}{ 建築物荷重指針 ${ }^{23)}$} & 34 & 38 & 44 & 36 & 40 & 50 \\
\hline
\end{tabular}

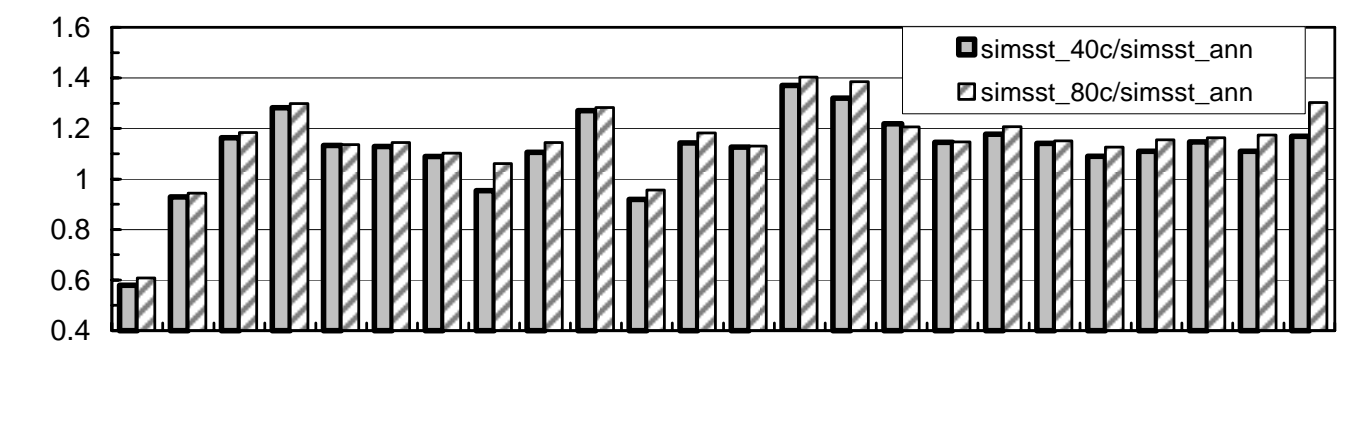

全平均

40 年後 $/$ 現在 $=1.12$ 80 年後 $/$ 現在 $=1.15$ 九州·四国

40年後 /現在 $=1.06$ 80 年後 /現在 $=1.09$ 谷の他

40 年後 / 現在 $=1.16$ 80 年後 $/$ 現在 $=1.19$

(1)シミュレーシジルでの現在と将来の風速比

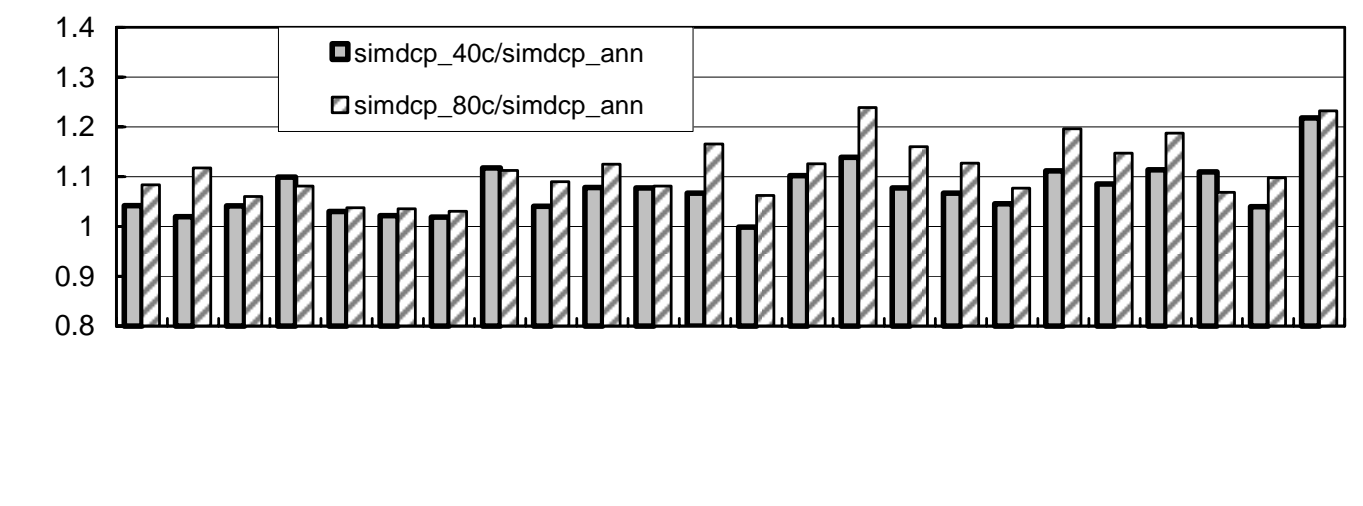

全平均

40 年後 /現在 $=1.07$ 80 年後 $/$ 現在 $=1.11$ 九州·四国 40 年後 $/$ 現在 $=1.05$ 80 年後 $/$ 現在 $=1.08$ 光の他

40 年後 $/$ 現在 $=1.09$ 80 年後 $/$ 現在 $=1.14$

図 - 17100 年再現期待風速の変化

\section{5 .結論}

本研究においては, 既往の台風シミュレーション手法 を発展させ，海面水温の影響を導入した新たな台風シミ ユレ一ション手法を構築した 乥して, 弚れを用いて現在 及び将来の海面水温 日本南海で 80 年間に $2 \sim 3{ }^{\circ} \mathrm{C}$ の 上昇が予測される)を使った台風シミュレーションを実施 し, 海面水温の変化が日本各地の台風強度特性に与え る影響について定量的な分析を行った.以下に得られ た結果を述べる。

1)台風シミュレーシシンでの 6 時間後の值を予測する線 形回帰式に海面水温項を導入したことで,導入しない 場合よりもわずかではあるが全般に相関が上昇した . このことより，海面水温を考慮しても既往のシミュレー ション手法と同程度か炎れ以上の精度でシミュレーシ
ヨンが可能であり,海面水温の影響を台風シミュレー ションで考慮できたと言える.また，海面水温項に関し ては,中心気圧低下量にのみ取り込んだ方が, 移動 速度にも取り込んた場合よりも台風通過数の点におい て妥当である結果を得たが，この点に関してはさらに 検討が必要である。

2)海面水温を考慮した現在と将来の海面水温上昇ケ一 スのシミュレーショコを比較すると,海面水温上昇で台 風通過数は日本の各地域で概ね増加する結果となつ た.地域によるばらつきはあるものの 40 年後 ,80 年後 に相当する海面水温上昇で光れ光れ最大で $50 \%$ 程 度, $100 \%$ 程度の台風通過数の増加割合を示した。

3)台風の中心気圧低下量については,日本南海,関東 以西, 北海道東部での将来の期待值か増大するが， 東北，北海道南西部では逆に減少することが予想さ 
れる.中心気圧低下量にのみ海面水温を取り込んだ シミュレーションでは , 40 年後, 80 年後に相当する海 面水温上昇で中心気圧低下量が全地域平均で, 光

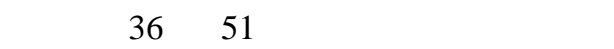

4)日本の 24 地点において,台風シミュレーシジの結果 から海面水温の変化か将来の再現期待風速へ与える 影響について解析を行つた.海面水温の影響を中心 気圧低下量にのみ考慮するか, 移動速度にも考慮す るかによって若干の違いがあるが, 海面水温が上昇 する将来では 100 年再現期待風速も概ね全ての地点 で上昇する結果となった .光して，弚の上昇率を見ると， 24 地点の平均で 40 年後, 80 年後に相当する海面水

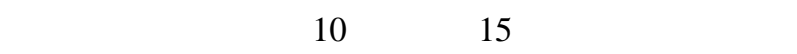
昇する結果となった .また,九州, 四国の上昇率は全 地点平均よりも低く, 兴の他の地点では逆に高くなっ た .

今後は, 各パラメ久ーの確率モデルの再検討, 海面水 温項のよりよい評価方法などに関する検討を行って，シ シュレーションの精度を高めるとともに ,シミュレーシジを 重ねることで, 海面水温の変化か将来の台風強度特性， 再現期待風速に与える影響をさらに詳細に検討する必 要がある.

\section{参考文献}

1）饒村曜,続·台風物語，財)日本気象協会, 1993 .

2）気象庁，地球温暖化予測情報第 1巻 CD-ROM), 1998.

3) 宮田利雄, 山田均, 勝地弘, 西脇三智子, 海面水温 の影響を考慮し台風シミュレーシシン,第17回風工学 シンポジウム論文集 ,pp.29-34,2002.

4) 高橋浩一郎，モデル台風による年最大風速超過確 率の推定, 本州四国連絡架橋調査 気象調査中間 報告兴の 2)，気象庁，pp.1-33,1964.

5) Russell, L. R., Probability Distributions for Hurricane Effects, J. of Waterways, Harbors and Coastal Engineering Div., ASCE, Vol.97, No.WW1, pp.139-154, 1971.

6) Tryggvasaon, B. V., Surry, D. and Davenport, A. G., Predicting Wind-Induced Response in Hurricane Zones, J. of ST, ASCE, Vol.102, No.ST12, pp.2333-2350, 1976.

7) Georgiou, P. N., Davenport, A. G. and Vickery, B. J., Design Wind Speeds in Regions Dominated by Tropical Cyclones, J. of WEIA, Elsevier, Vol.13, pp.139-152, 1983.
8) 藤井健, 光田寧, 台風の確率モデルによる強風のシ ミュレーション, 日本風工学会誌, 第 28号,pp.1-12, 1986.

9) 光田寧, 藤井健, 台風による風災害の予測, 日本風 工学会誌,第 72号,pp.73-91, 1997.

10）松井正宏,孟岩,日比一喜, 実測と台風モデルの 平均化時間の違いを考慮した台風シミュレーションに よる年最大風速の予測手法，日本建築学会構造系 論文集，第506号,pp.67-74, 1998.

11）安井八紀, 大熊武司,吉江慶祐, 片桐純治, 廣川 雅一，モンテカルロ法を用いた台風シミュレーション に関する研究,第16回風工学シンポジウム論文集, pp.65-70,2000.

12）西岡秀三, 原沢英夫, 地球温暖化と日本 - 自然 人への影響予測 - , 古今書院 , 1997 .

13) Gray, W. M., Tropical Cyclone Genesis, Dept. of Atmos. Sci. Paper No.234, Colorado State Univ., 1975.

14) Ryan, B. F., Watterson, I. G. and Evans, J. L., Tropical Cyclone Frequencies inferred from Gray's Yearly Genesis Parameter: Validation of GCM Tropical Climates, Geophysical Research Letters, Vol.19, No.18, pp.1831-1834, 1992.

15) Emanuel, K. A., The Dependence of Hurricane Intensity on Climate, Nature, Vol.326, pp.483-485, 1987.

16）筒井純一, 平口博丸, 北太平洋の海面水温変動と 台風特性の変化に関する統計解析, 電力中央研究 所報告 ,U93050,1994。

17) 山田真吾, 北西太平洋における海面水温と台風強 度の関係について,日本気象学会 1995年春季大会 講演予稿集,pp.48, 1995.

18) DeMaria, M. and Kaplan, J., Sea Surface Temperature and the Maximum Intensity of Atlantic Tropical Cyclones, J. of Climate, Vol.7, pp.1324-1334, 1994.

19) 丸山康樹,平口博丸，筒井純一,地球温暖化と台 風の関係について, 電力土木,No.254,pp.83-89， 1994.

20) Sugi, M., Noda, A. and Sato, N., Influence of the Global Warming on Tropical Cyclone Climatology: An Experiment with the JMA Global Model, J. of the Meteorological Society of Japan, Vol.80, No.2, pp.249-272, 2002.

21) Yoshizumi, S., On the Asymmetry of Wind Distribution in the Lower Layer in Typhoon, J. of the Meteorological Society of Japan, Vol.46, No.3, pp.153-159, 1968.

22) 道路橋耐風設計便覧，日本道路協会，1991.

23）建築物荷重指針 同解説, 日本建築学会, 1993 . 